Veröffentlichungsreihe der Abteilung Institutionen und sozialer Wandel des

Forschungsschwerpunkts Sozialer Wandel, Institutionen und Vermittlungsprozesse des Wissenschaftszentrums Berlin für Sozialforschung

ISSN 1615-7559

FS III 00-206

\title{
Eastward Enlargement of the European Union and the Identity of Europe
}

Dieter Fuchs and Hans-Dieter Klingemann

Berlin, September 2000

Wissenschaftszentrum Berlin für Sozialforschung gGmbH (WZB)

Reichpietschufer 50, D-10785 Berlin,

Telefon (030) 2549 1-0 
Zitierweise:

Fuchs, Dieter, and Hans-Dieter Klingemann, 2000:

Eastward Enlargement of the European Union and the Identity of Europe Discussion Paper FS III 00-206.

Wissenschaftszentrum Berlin für Sozialforschung (WZB). 


\title{
Zusammenfassung
}

Die Herausbildung eines europäischen Demos mit einer kollektiven Identität ist eine der Voraussetzungen zur Behebung des Legitimitätsproblems der Europäischen Union (EU). In der Analyse wird empirisch zu klären versucht, ob es hinreichende Gemeinsamkeiten in den politischen Wertorientierungen der Europäer gibt, die eine kollektive Identität begründen können. Vor allem angesichts der Osterweiterung der EU stellt sich die Frage, ob die kulturelle Heterogenität in Europa nicht zu groß ist, um einen Europäischen Demos zu ermöglichen. Hinsichtlich der politischen Wertorientierungen der Bürger in den europäischen Ländern lässt sich eine West-Ost-Achse identifizieren. Das Ausmaß demokratischer Einstellungen nimmt nach Osten hin ab, und zugleich nimmt das Ausmaß etatistischer Orientierungen zu. Relative Schwellenwerte innerhalb dieser Achse lassen sich zwischen Westeuropa einerseits und Mittel- und Osteuropa andererseits feststellen und innerhalb Mittel- und Osteuropas zu den slawischen Nachfolgestaaten der Sowjetunion. Diese Befunde entsprechen teilweise der Theorie der Zivilisationskreise von Huntington.

\begin{abstract}
The constitution of a European demos with a collective identity is one of the preconditions for adjusting the legitimacy problem of the European Union (EU). The analysis attempts to clarify empirically whether there is sufficient commonality regarding Europeans" political value orientations to substantiate a collective identity. Particularly in view of the European Union's eastward enlargement, the question arises whether widespread cultural heterogeneity in Europe allows the formation of a European demos at all. In Europe we can identify a West-East axis of political value orientations. Democratic attitudes decrease the further to the East while at the same time there is an increase in etatist orientations. Thresholds can be observed which distinguish western European countries on the one hand and central and eastern European countries on the other. Within the group of central and eastern Europe a further distinction can be made between the three Slavic republics of the former Soviet Union and the rest of the countries. These findings support Huntington's theory of civilizations.
\end{abstract}



Dieter Fuchs and Hans-Dieter Klingemann

\section{Eastward Enlargement of the European Union and the Identity of Europe*}

\section{The Issue}

Until the Maastricht Treaties (1991), the European Community was primarily an economic community legitimated by economic efficiency criteria (Lepsius 1999). Maastricht, however, initiated the transformation of the Community into a European Union (EU), which continued with the Treaty of Amsterdam (1997). These treaties vest greater powers in EU institutions. The EU is thus increasingly a supranational regime, substantially restricting member states' scope for action, and whose decisions directly affect citizens' lives. These decisions also affect politically sensitive areas that had hitherto been dealt with at the nation-state level (including social and moral issues). These developments have been politicising the EU and, consequently, engendering legitimation problems. The discussion on the democratic deficiencies of the EU, which has arisen only since this transformation of the European Community, is an expression of the legitimation issue. Many feel the EU can attain democratic legitimacy only if a European demos with a collective identity takes shape (Grimm 1995; Kielmansegg 1996; Scharpf 1999). This can be maintained even if the democratic deficiencies of the EU were to be eliminated institutionally by substantially expanding the rights of the European Parliament. A viable European democracy requires a European demos that conceives of itself as a collectivity, considers itself represented by the Parliament, and makes the latter the addressee of relevant demands. However, in view of the cultural plurality and heterogeneity of European nation states, it is doubtful whether the constitution of a European demos with a tenable collective identity is possible at all (Lepsius 1999).

A further transformation of the EU must increase these doubts. At the 1992 Copenhagen summit, the then EU heads of government decided that the countries of Central and Eastern Europe could become members of the EU if they so desired and if they meet certain criteria for accession. There are now a number of candidates for accession, and negotia-

* The chapter is to appear in Jan Zielonka (ed.). Europe Unbound: Enlarging and Reshaping the Boundaries of the European Union, Cambridge: Cambridge University Press, forthcoming. We would like to thank Seymour Martin Lipset for his critical reading of the paper and his helpful comments. 
tions are being conducted with a first group of countries. For a number of reasons, eastward enlargement is likely to make it even more difficult to develop a European identity. First, because the territorial limits of Europe are vague: where does it end in the east, or where should it end? A clearly defined territory is at least a useful, indeed necessary precondition for the cognitive constitution of an "us" that distinguishes itself from "others" and which is the vehicle of a collective identity (Fuchs, Gerhards, and Roller 1993). Second, including additional nation- states increases the cultural plurality of the EU still more. And, third, it cannot be excluded that, over and above this pluralisation, there is a cultural gap between Western Europe and Central and Eastern Europe. Such a gap can be caused by different traditions and historical events in the distant past but also by socialisation and experience in the opposing societal systems in which people in Eastern and Western Europe lived from the end of the Second World War until the collapse of the communist states.

A collective identity can develop only on the basis of commonality among the members of a definable community. It is an open question how comprehensive this commonality must and can be in the case of a European demos. We assume that homogenising the plurality of national cultures to form a European nation is a project that is neither practicable nor useful. For a European demos before which the EU regime can be legitimated and which participates in the democratic processes in Europe, common political values and behaviours are presumably quite sufficient. With this premise in mind, our empirical goal is to establish the extent to which such commonality exists in individual countries or whether there are serious and systematic differences.

This analysis is structured by two theoretical considerations. First, we assume that political value orientations and behaviours can be organised in meaningful patterns. In determining these patterns we draw on the concepts of the democratic community and various types of democratic community. The most important criterion is support for democratic rule and rejection of autocratic rule. The greatest possible agreement on these preferences is a necessary condition for a European demos. However, fundamental support for democracy reveals nothing about the ideas held on how democracy should be specifically implemented and structured. To settle this question, further values and behaviours must be taken into account. They form specific patterns, and, with reference to the democratic theory debate, we distinguish different types of democratic community.

Second, our analysis of differences in political values and behaviours considers not only individual countries but groups or families of countries. The country groups are distinguished on the basis of criteria proposed by Huntington (1996), Lipset (2000) and Reisinger (1999). 
The planned analysis can contribute only to discovering the potential for the formation of a European demos with a collective identity. Empirically established, objective commonality can have an identity-forming effect only if it is perceived as such and finds its place in the self-description of the collectivity. However, this transformation of objective commonality into the subjective self-understanding of a collectivity presupposes a great deal. In the case of a European demos, one of the prerequisites is certainly a European public (Gerhards 1993) that can make latent commonality visible and allow it to become part of people's self-conception. However, this is not the subject of our study. We limit ourselves to the priority investigation of whether there is such commonality at all.

The study proceeds in three steps. First, the concepts of democratic community and types of democratic community are presented. The empirical analysis follows. It begins by explicating the classification of countries and by stating a number of theoretical expectations. In the empirical analysis itself, we first establish the extent to which the societal community in individual countries and groups of countries can be considered democratic at all. We then determine what type of democratic community predominates in these countries and groups of countries. In a third and final step, we summarise the empirical findings and draw a number of conclusions on the formation of a European demos with a collective identity.

\section{The Concept of the Democratic Community}

The demos of a democracy is a certain form of societal community. And like every societal community it is constituted through two mechanisms (Fuchs 1999b, 2000). First, by drawing a boundary that defines who is included and who is excluded. In modern societies, nationality provides a formal boundary. But it can have a constitutive effect only if it is subjectively assimilated by members of the community. This requires cognitively identifiable criteria, and one important such criterion is a clear territorial boundary. Second, a societal community takes shape through the ties between members on the basis of things actually or presumed to be shared. Only through these two mechanisms does a mere aggregate of individuals become a community that presents and can describe itself as such, and with which members can also identify.

The form of societal community that interests us is the demos, which, as the subject of a democratic form of government, should be a democratic community (Berry 1989; Chapman and Shapiro 1993). If it is to be accepted as such, it has to exhibit certain minimal characteristics. The institutional order of a democracy (kratos) can function only if there is a corresponding community (demos). In determining the properties of a democratic 
community we draw on an analytical model that divides democracy into three hierarchically structured levels (Fuchs and Roller 1998; Fuchs 1999a, 2000). The topmost level is that of political culture, whose constitutive elements are the fundamental values of a democracy. The next level is that of political structure, which consists of the democratic system of government of a country, generally laid down by the constitution. This structure can be understood as a selective implementation of the cultural values of a community for the action context of politics, and this system of government is also legitimated by recourse to these values. The lowest level in the hierarchy is that of the political process. The political process is concerned with the realisation of the collective goals of a community by the actors. Their action is controlled by the political structure, and this means, among other things, that normative expectations about the behaviour of political actors are associated with the constituted system of government in a given country. The three levels thus form a control hierarchy that begins with culture and ends with the process or actual activity on the part of actors. What attributes must a community have at these three levels if it is to be deemed democratic?

At the cultural level, a democratic community is characterised above all by support for the fundamental values of democracy. They include the idea of self-government or sovereignty of the people. And this includes mutual recognition of citizens as free and politically equal. Since the birth of democracy in ancient Athens, the two values freedom and political equality have been essentially bound up with that of democracy (Sartori 1987; Hansen 1991).

A democratic community cannot be as clearly identified at the structural level as at the cultural level. On the one hand it must be expected that the regime in the citizens' own country is supported in so far as it is a democracy and not an autocracy. Otherwise approval of the idea of democracy would be completely non-committal. On the other hand, the idea of a democracy can be institutionally embodied in different ways. For this reason many people may basically want a democracy but not in the form that exists in their country. People may therefore support or criticise the democracy implemented in their country for a variety of reasons (Fuchs 2000). They may support it because it is a democracy and as such has institutionalised the idea of democracy. They may criticise it because they feel that the reality of democracy in their country fails to meet their own normative ideas of democracy, and because they also assume there are alternative forms of implementation that produce a better democratic reality. Such people can be described as "critical democrats" (Klingemann 1999). Both possibilities are compatible with the prerequisites for a democratic community.

The process level is concerned with the realisation of political objectives by producing collectively binding decisions. In pluralistic societies, such goals are always controversial, 
and conflicts about them are the very essence of democratic processes. A democratic community is thus not characterised by consensus, however understood, about the political goals to be attained but only by actual compliance with the procedural norms for taking action as laid down by the constitution, and which are intended to regulate everyday political conflicts.

Figure 1: Operational Definitions of a Democratic Community

\begin{tabular}{|c|c|c|}
\hline System level & Basic elements & Operational definitions \\
\hline Culture & Values & $\begin{array}{l}\text { The stronger support is for a democracy and the more } \\
\text { strongly autocracy is rejected, the more closely the } \\
\text { societal community will correspond to a democratic } \\
\text { community. } \\
\text { The more strongly other citizens are recognised as free } \\
\text { and equal, the more closely the societal community will } \\
\text { correspond to a democratic community. }\end{array}$ \\
\hline Structure & $\begin{array}{l}\text { Rules and } \\
\text { institutions }\end{array}$ & $\begin{array}{l}\text { The stronger support for or critique of democracy in one's } \\
\text { own country is based on democratic norms, the more } \\
\text { closely the societal community will correspond to a } \\
\text { democratic community. }\end{array}$ \\
\hline Process & Actions & $\begin{array}{l}\text { The less citizens use force as a political means, the more } \\
\text { closely the societal community will correspond to a } \\
\text { democratic community. } \\
\text { The more closely citizens conform to the democratically } \\
\text { determined norms of action, the more closely the societal } \\
\text { community will correspond to a democratic community. }\end{array}$ \\
\hline
\end{tabular}

Figure 1 shows these attributes of a democratic community in the form of "the more - the more" statements. They constitute operational definitions that provide a point of reference for later empirical analysis. As we have seen, a democratic community is characterised at the process level by compliance with the democratically established legal norms. The prohibition of violence or force as a political instrument has pre-eminent status among these legal norms, because it affects the essence of successful integration into a community. The figure therefore contains an independent operational definition of force as a means of politics.

Having established the characteristics of a democratic community, we proceed to differentiate different types. For the purpose of our study we combine a theoretical with a pragmatic approach. Theoretically, we follow the contemporary discussion in political philosophy (including Nozick 1974; Barber 1984; Taylor 1989; Etzioni 1993; Rawls 1993), and pragmatically we are guided by indicators available in the 1995-1999 World Values Sur- 
vey. We begin with a simplified description of the types. We bring in a dimension at the cultural level that has hitherto been neglected by empirical democracy research, namely the ethos of a community. It has two points of reference, first, the ethical values by which a person orders his life and, second, the ethical values governing relations with other members of the societal community.

This ethos of the community is the subject of one of the most important democracy theory debates to have been conducted in recent decades. We will not deal with it in detail at this point but merely reiterate the aspects that are important for our analysis - the differentiation of the democratic community. The debate has been provoked by the tension between the freedom of individuals and the demands of the community. Differing normative positions are apparent primarily in the priority given to the one or the other. This general continuum, with the poles individualism and community, can be divided into two dimensions, which have already been mentioned in discussing the ethos of the community. The one dimension addresses the fundamental question who bears the principal responsibility for shaping and determining a person's life: the individual himself or the state, which represents a specific form of community institutionalisation. The other dimension is concerned with the just as fundamental question of how relations between individuals should be. The one alternative is performance-driven competition between individuals in the various marketplaces and the other is co-operation and solidarity in dealing with one another (Chapman and Shapiro 1993). Crossing these two dichotomous dimensions produces a typology with four normative models of democracy and the corresponding types of democratic community: libertarian, liberal, socialist, and republican (see Figure 2).

The contrasting and, as it were, pure models are the libertarian and socialist communities. On both dimensions they give clearest priority to one or other alternative. The liberal model differs from the libertarian primarily through equality of opportunity in competition between individuals in the economic and political markets as a criterion of justice. And justice is the most important standard by which to evaluate societal institutions. The most prominent advocate of this model is Rawls (1993). Given differences in ability and temperament, equality of opportunity can be ensured only through legal regulation and redistribution by government. Government thus plays an extremely important role in shaping the life of the individual. The liberal model differs from the socialist model in three ways. First, redistribution by government is concerned only with the most equal possible distribution of the primary goods that are absolutely necessary for the individual to organise his life autonomously. Second, the principles of competition and performance are constitutive for the relationship between individuals in everyday interaction in the marketplace, in politics, and in other areas of society. And, third, in the event of conflict, individual freedom always has unrestricted priority over the equal distribution of the other primary goods. 
Figure 2: Types of a Democratic Community

\begin{tabular}{|c|c|c|c|}
\hline & & Respons & wn fate \\
\hline & & Self & State \\
\hline & Competition & Libertarian & Liberal \\
\hline & $\begin{array}{l}\text { Co-operation } \\
\text { (Solidarity) }\end{array}$ & Republican & Socialist \\
\hline
\end{tabular}

Among other things, this means that, in contrast to the socialist model, basic social rights ought not to be included in the constitution. Ensuring equality of opportunity can be only a political task, which, in practical terms, results in the establishment of a more or less comprehensive welfare state. Overall, the role of government in the liberal model is thus relatively less restricted than in the socialist model. This difference is not visible in the dichotomised typology. From an institutional point of view, the ethical values of the libertarian community mean as little government as possible and as comprehensive a market as possible; and those of the socialist community mean a comprehensive welfare state and a limited market. The liberal community occupies an intermediate position.

The republican community differs most strongly from the others. Moreover, it can be considered the normatively most demanding. In contrast to the liberal community, common values are of crucial importance, and, in case of doubt, are given priority over the unrestricted freedom of the individual. The lifestyle of a republican community is "essentially co-operative and solidaristic" (Post 1993). It differs from the liberal and especially from the socialist community by a fundamentally anti-etatist and anti-paternalism attitude. In this regard it resembles the libertarian community. According to republican ideas, community values should by implemented not by government, and thus on behalf of the citizens, but by the community of citizens themselves (Etzioni 1996). For this reason the selforganisation of the citizenry in local units is an essential republican postulate. The republican community is thus a participatory and solidary community. The solidarity concept differs considerably from that upheld in the socialist community. It presents itself as voluntary support for people in need through no fault of their own, or as voluntary charitableness. Solidarity in a socialist community, by contrast, is exercised through collectively binding decisions by the state and, moreover, is characterised by a strong concept of equality. 
Figure 3: Types of a Democratic Community (schematic description)

\begin{tabular}{|c|c|c|c|c|}
\hline & Libertarian & Liberal & Socialist & Republican \\
\hline \multicolumn{5}{|l|}{ Cultural level } \\
\hline $\begin{array}{l}\text { Responsibility } \\
\text { for one's own life }\end{array}$ & Self & $\begin{array}{c}\text { Self } \\
+ \\
\text { State }\end{array}$ & State & Self \\
\hline $\begin{array}{l}\text { Relationship } \\
\text { with others }\end{array}$ & Competition & $\begin{array}{c}\text { Competition } \\
+ \\
\text { Equal } \\
\text { opportunities }\end{array}$ & $\begin{array}{l}\text { Solidarity } \\
\text { (abstract) }\end{array}$ & $\begin{array}{c}\text { Solidarity } \\
\text { (specific) } \\
\text { Trust }\end{array}$ \\
\hline $\begin{array}{l}\text { Ethic idea of the } \\
\text { good }\end{array}$ & & Tolerance & & Tolerance \\
\hline \multicolumn{5}{|l|}{ Structural level } \\
\hline $\begin{array}{l}\text { Ownership of } \\
\text { means of } \\
\text { production }\end{array}$ & $\begin{array}{c}\text { Private } \\
\text { ownership }\end{array}$ & $\begin{array}{c}\text { Private } \\
\text { ownership }\end{array}$ & $\begin{array}{c}\text { Private } \\
\text { ownership } \\
+ \\
\text { State property }\end{array}$ & \\
\hline $\begin{array}{l}\text { Management of } \\
\text { enterprises }\end{array}$ & Entrepreneur & & $\begin{array}{c}\text { Entrepreneur } \\
+ \\
\text { Employee }\end{array}$ & \\
\hline Process level & & & & \\
\hline $\begin{array}{l}\text { Political } \\
\text { motivation }\end{array}$ & & & & High \\
\hline $\begin{array}{l}\text { Civic } \\
\text { engagement } \\
\text { (voluntary } \\
\text { associations) }\end{array}$ & & & & High \\
\hline
\end{tabular}

The ideas about a republican community that were developed in the context of normative democracy theory have been taken up in an empirical research context especially by Putnam (1993). Putnam himself uses the concept of civic community. The dimensions and attributes of the civic community are compatible with our analytical distinctions. Putnam assumes from the outset that the civic community is democratic, and accordingly exhibits corresponding attitudes towards the democratic system of government. He therefore concentrates on the ethos of the community and the behaviour of its members that it engenders. At the level of political culture, Putnam sees several values as characteristic of the community. In the first place he emphasises political equality, while stressing - fully in keeping with the republican tradition - that this includes equal rights and duties for all. This value is particularly important for the relationship between individual members of the community and its institutions. The other values are concerned with interactions among 
members of the community. They should be guided by solidarity, tolerance, and trust. The citizens of a civic community are thus explicitly not egoistic-rational people, as is assumed, for example, in the libertarian model of democracy. A decisive characteristic of a civic community is, according to Putnam, a strong commitment among citizens to political participation. Putnam makes two specifications in this regard. First, an orientation towards the public good: "Participation in a civic community is more public-spirited, more oriented to shared benefits" (Putnam 1993: 88). On the other hand, the decisive form of participation is in voluntary associations. According to Putnam, active membership in voluntary associations contributes to the generation of the values mentioned and the associated ability and willingness for co-operative behaviour in realising the public good.

Figure 3 shows the four types of democratic community schematically in terms of the attributes described above. The two dimensions underlying the typology in Figure 2 have naturally been taken into account. A characteristic is used in describing a type of democratic community only if this is clearly justified on the basis of the democracy theory discussion.

\section{Empirical Analysis}

\subsection{Classification of Countries and Theoretical Expectations}

As the predecessor of the European Union, the European Community came into being during the period of the East-West conflict. It therefore included only Western European states, with France and Germany as the core countries. They provided relative economic and cultural homogeneity, and the border question did not arise. To the west, north, and south, the border was defined by the coastline, and to the east by the Iron Curtain. After the collapse of communism, the eastward border dissolved, and the question where the eastern bounds of Europe ought to be set and who should be considered potential members of the EU came onto the agenda (Huntington 1996).

Depending on what criteria are applied, this question finds a variety of answers. The criterion of our study is the similarity of political communities in the countries of Central and Eastern Europe to those of the Western European countries that have hitherto constituted the European Union. The basic assumption is that the potential for the formation of the European demos with a collective identity is proportionate to the similarity of political values and behaviours. Before we tackle the empirical analysis, we classify the countries under study and attempt on this basis to formulate what we expect of the analysis. 
Political values and behaviours are influenced by various factors; most importantly, perhaps, by durable cultural traditions (Putnam 1993, Huntington 1996, Inglehart 1998). A useful starting point for classifying countries is thus the distinction between civilisations drawn by Huntington (1996). He postulates a historical cultural borderline within Europe that divides the Western-Christian peoples from the Muslim and Orthodox peoples. This dividing line ultimately goes back to the division of the Roman Empire in the $4^{\text {th }}$ century, consolidated in the $16^{\text {th }}$ century. If one were to take account only of this cultural border, the frontier of Europe would be clearly definable. It would run where Western Christianity ends and Islam begins (Huntington 1996). This definition is based above all on religion, and this is dichotomised: Protestant and Catholic vs. Orthodox and Muslim. For the purposes of our analysis, this is too great a simplification. We therefore draw on two further criteria to produce a more differentiated classification of countries, basing our procedure on democracy theory approaches and findings (Reisinger 1999; Lipset 2000).

These two additional criteria are the different empires in which the peoples concerned lived for centuries, namely the British, Habsburg, Russian, and Ottoman empires. The links between these empires and specific religions (Protestant, Catholic, Orthodox, and Muslim) are obvious, but it can be assumed that the respective system of government has an independent impact on fundamental values. They are, for example, to be associated with the extent of autocratic rule in the different empires or with the different degree of separation between State and Church.

The Soviet Empire can be regarded as a specific variant. Russia formed the centre of this empire, and its sphere of influence included first the other Soviet republics, and second the countries of Central and Eastern Europe within the Iron Curtain. Unlike the other empires, the Soviet Union and its satellite states had definitely no religious basis. The impact on the political attitudes and behaviours of the citizenry is affected by the autocratic system of government and the egalitarian ideology (Fuchs 1999b, Rohrschneider 1999). Reisinger (1999) suggests that this impact varies depending on the length of time during which a country had a Leninist regime.

In addition to religion, empire and Leninist regime, we draw on a fourth characteristic, the level of socio-economic modernity. It is operationalized by per capita GDP. The modernity and wealth of a country are among the most important preconditions for the formation and stability of a democracy and for the development of democratic and liberal values. This has been repeatedly established by Lipset (1959, 1994, 2000), and can be considered one of the best confirmed findings of empirical democracy research.

Tables 1 and 2 classify countries in terms of the dimensions explained. Description in terms of "empire" and "modernity" (Table 1) is relatively unproblematic. It is a little more complicated with "religion", since most countries are mixed in this respect. Table 2 shows 
the shares of individual religions in each country as a percentage. In the last column (CL) the country is classified in terms of modal denomination. The columns PC (Protestant and Catholic) and OM (Orthodox and Muslim) demonstrate the dominant dividing line postulated by Huntington (1996).

Countries have been assigned to one of seven groups on the basis of the four dimensions (see Tables 1 and 2). Although our study is concerned with European countries, the United States, Australia, and New Zealand have also been taken into account. According to Huntington (1996), these countries form an independent culture complex within WesternChristian civilisation that differs systematically from Europe. This difference has recently been empirically established at the level of political attitudes and behaviours, as well (Fuchs and Klingemann 2000). Including this group of countries provides a contrastive backdrop to the particularity of European nations. Moreover, they most clearly represent one of the types of democratic community that we have identified (libertarian community).

We have chosen to label the groups of countries by geographical region. Such regions are relatively neutral concepts, while being, in a certain sense, effective factors in generating common characteristics. Spatial proximity between countries and peoples facilitates communication and increases the probability of similar historical experience. All four dimensions relate systematically to the formation and stability of democracies on the one hand, and to the development of democratic and liberal attitudes and behaviours on the other (Huntington 1996; Reisinger 1999; Lipset 2000). ${ }^{1}$ Since we cannot make any precise assumptions about the relative weight of individual dimensions and relations between the various scale points, only limited a priori assumptions are possible on the basis of this classification. We begin with the "democratic community", which is characterised by acceptance of the fundamental values of every democracy. In this regard, the situational factor of the collapse of the communist systems is likely to have an effect. We therefore expect a democracy to be supported by a majority in every country. The factors we have used in classifying countries would therefore have to take effect in relative differences between countries and groups of countries. If the major historical dividing lines postulated by Huntington (1996), separating the Western-Christian peoples from the Muslim and Orthodox peoples, is indeed the decisive borderline, the Anglo-American, Western European, Central European, and Baltic countries would be more democratic than the South-Eastern and Eastern European lands.

If all four dimensions - not only "religion" but also "empire", "Leninist regime" and "modernity" - are taken into account, expectations are somewhat more differentiated. On the basis of these dimensions we can posit the following ordinal sequence in the extent

1 Religion: 1. Muslim or Orthodox, 2 Catholic, 3 Protestant or secular; Empire: 1 Ottoman or Russian, 2 Hapsburg, 3 British or none; Leninist regime: 1 yes (duration in years), 2 no; modernity: continuous (the higher the score the more favourable to democracy and vice versa). 
Table 1: Cultural Heritage. A Classification of Countries by Empires, Duration of Leninist Regimes and Modernity

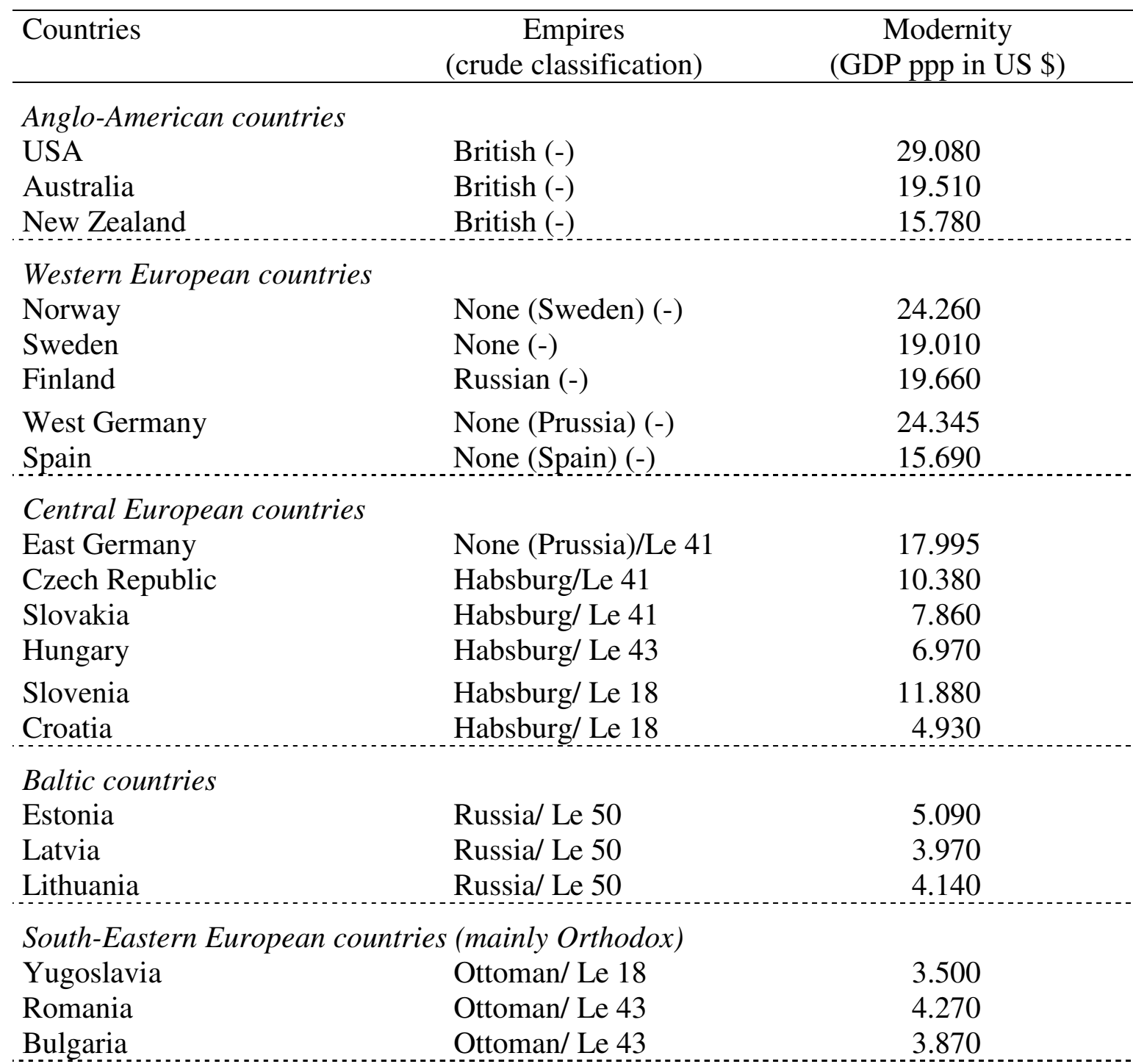

South-Eastern European countries (mixed-Muslim)

$\begin{array}{lll}\text { Macedonia } & \text { Ottoman/ Le } 18 & 3.180\end{array}$

Bosnia-Herzegovina Ottoman/ Le $18 \quad 2.358$

Albania $\quad$ Ottoman/Le 45 2.170

Eastern European countries

\begin{tabular}{lll} 
Russia & Russia/ Le 74 & 4.280 \\
Ukraine & Russia/ Le 74 & 2.170 \\
Belarus & Russia/ Le 74 & 4.820 \\
Moldova & Ottoman/ Le 50 & 1.450 \\
\hline
\end{tabular}

$\mathrm{Le}=$ years of Leninist rule (Reisinger 1999 and own calculations for Albania, East Germany; and the former Yugoslav states; Modernity: GDP purchasing parity power in US dollars 1997. 
Table 2: Cultural Heritage. A Classification of Countries by Denomination

\begin{tabular}{|c|c|c|c|c|c|c|c|c|c|}
\hline Countries & $\begin{array}{l}\mathrm{P} \\
\%\end{array}$ & $\begin{array}{l}\mathrm{C} \\
\% \\
\end{array}$ & $\begin{array}{c}\mathrm{PC} \\
\%\end{array}$ & $\begin{array}{l}\mathrm{O} \\
\% \\
\end{array}$ & $\begin{array}{l}\mathrm{M} \\
\%\end{array}$ & $\begin{array}{c}\mathrm{OM} \\
\%\end{array}$ & $\begin{array}{l}\mathrm{S} \\
\% \\
\end{array}$ & $\begin{array}{l}\mathrm{T} \\
\% \\
\end{array}$ & $\mathrm{CL}$ \\
\hline \multicolumn{10}{|c|}{ Anglo-American countries } \\
\hline USA & 36 & 25 & 61 & 0 & 0 & 1 & 18 & 80 & $\mathbf{P}$ \\
\hline Australia & 48 & 26 & 74 & 1 & 1 & 2 & 3 & 79 & $\mathbf{P}$ \\
\hline New Zealand & 60 & 14 & 74 & 0 & 0 & 0 & 4 & 78 & $\mathbf{P}$ \\
\hline \multicolumn{10}{|c|}{ Western European countries } \\
\hline Norway & 82 & 1 & 83 & 1 & 1 & 2 & 4 & 89 & $\mathbf{P}$ \\
\hline Sweden & 81 & 5 & 86 & 1 & 4 & 5 & 1 & 92 & $\mathbf{P}$ \\
\hline Finland & 80 & 3 & 83 & 2 & 0 & 2 & 1 & 86 & $\mathbf{P}$ \\
\hline West Germany & 39 & 33 & 72 & 0 & 1 & 1 & 1 & 74 & $\mathbf{P}$ \\
\hline Spain & 1 & 82 & 83 & 0 & 0 & 0 & 1 & 84 & C \\
\hline \multicolumn{10}{|c|}{ Central European countries } \\
\hline East Germany & 18 & 5 & 23 & 0 & 0 & 0 & 1 & 24 & $\mathbf{T}$ \\
\hline Czech Republic & 2 & 39 & 40 & 0 & 0 & 0 & 3 & 43 & $\mathbf{C}$ \\
\hline Slovakia & 10 & 73 & 83 & 0 & 0 & 0 & 3 & 86 & $\mathbf{C}$ \\
\hline Hungary & 17 & 55 & 72 & 2 & 0 & 2 & 1 & 75 & $\mathbf{C}$ \\
\hline Slovenia & 2 & 69 & 71 & 2 & 1 & 3 & 1 & 75 & $\mathbf{C}$ \\
\hline Croatia & 0 & 82 & 82 & 1 & 1. & 1 & 1 & 85 & C. \\
\hline \multicolumn{10}{|l|}{ Baltic countries } \\
\hline Estonia & 10 & 0 & 10 & 16 & 0 & 16 & 2 & 28 & $\mathbf{T}$ \\
\hline Latvia & 19 & 18 & 37 & 18 & 0 & 18 & 5 & 60 & $\mathbf{P}$ \\
\hline Lithuania & 2. & 77 & 79 & 4 & 0 & 4 & 2 & 85 & $\mathbf{C}$ \\
\hline \multicolumn{10}{|c|}{ South-Eastern European countries (mainly Orthodox) } \\
\hline Yugoslavia & 1 & 6 & 7 & 64 & 8 & 72 & 2 & 81 & $\mathbf{O}$ \\
\hline Romania & 2 & 5 & 6 & 87 & 0 & 87 & 3 & 96 & $\mathbf{O}$ \\
\hline Bulgaria & 1. & 1. & 2 & 52 & 12. & 64 & 1 & 67 & $\mathbf{O}$ \\
\hline \multicolumn{10}{|c|}{ South-Eastern European countries (mixed-Muslim) } \\
\hline Macedonia & 0 & 1 & 1 & 45 & 24 & 69 & 0 & 70 & $\mathbf{O}$ \\
\hline $\begin{array}{l}\text { Bosnia- } \\
\text { Herzegovina }\end{array}$ & 2 & 14 & 16 & 26 & 27 & 53 & 1 & 70 & $\mathbf{M}$ \\
\hline Albania & 0 & 6 & 6 & 20 & 67 & 87. & 0 & 93 & M \\
\hline \multicolumn{10}{|c|}{ Eastern European countries } \\
\hline Russia & 0 & 0 & 0 & 48 & 5 & 53 & 1 & 54 & $\mathbf{O}$ \\
\hline Ukraine & 0 & 6 & 6 & 56 & 0 & 56 & 1 & 63 & $\mathbf{O}$ \\
\hline Belarus & 0 & 8 & 8 & 54 & 0 & 54 & 0 & 62 & $\mathbf{O}$ \\
\hline Moldova & 0 & 0 & 0 & 83 & 0 & 83 & 1 & 84 & $\mathbf{O}$ \\
\hline
\end{tabular}


to which a democratic community exists: (1) the Anglo-American and Western European countries (perhaps Spain and Finland might be somewhat marginal); (2) the Central European countries; (3) the Baltic countries; (4) the South-Eastern European countries (with the exception of Albania); (5) the Eastern European countries (including Albania). In all the following tables of empirical results, the groups of countries are listed in this presumed order. If one wishes to provide an empirically testable simplification, the extent to which a democratic community exists in individual countries can be assumed to vary along a geographical northwest-southeast axis.

Two central criteria were applied in differentiating between types of democratic community (see Figure 2). First, whom the citizens feel should bear primary responsibility for a person's fate (the individual himself or the state), and, second, how relations between fellow-citizens ought to be (competitive or solidary). The two criteria can also be understood as a specification of the more general individualism-collectivism dimension. In formulating our expectations we drew on a study by Lipset (1996). He postulates a substantial difference between American and European cultures, an "American exceptionalism". In this context he is concerned only with Western Europe. The distinction Lipset makes resembles that proposed by Huntington (1996) between North American and Western European cultures. However Lipset focuses on different aspects. In his view, the exceptionality of American culture has been primarily determined by the ethos of the Protestant sects that immigrated from Britain. Central to the American ethos is a marked individualism with a strong ethic of self-responsibility and an anti-etatist attitude. This has produced a society with a weak central government and a strong market. Another two features that characterize the American ethos also trace back to the traditions of the Protestant sects (Lipset 1996). On the one hand, this is a pronounced work ethic that derives ultimately from the idea of "predestination." On the other hand, it is an ethic moralism with respect to questions of good life and true action.

Lipset contrasts the American ethos with the etatist and solidary attitudes among Europeans, which have led to the formation of welfare states. Of the factors given in Tables 1 and 2 that shape the political attitudes and behaviours of the citizenry, Lipset thus cites British origins and the tradition of the British Empire, and the religion of the Protestant sects. However, since the ethic of the Protestant sects and the structure of the political and economic systems grounded on it are considered the most important causes for the extraordinarily successful modernisation process in the United States, the modernity factor also comes into play. On the basis of Lipset's study we can formulate a number of expectations about the type of democratic community in the countries under study.

Lipset (1996) takes no account of Central and Eastern European countries. If we assume that autocratic regimes - like those of the Ottoman and Russian Empires and the Soviet 
imperium - foster etatist orientations and weaken individualist attitudes, we can on this basis formulate expectations about the type of democratic community to include the countries of Central and Eastern Europe. We restrict ourselves to the two criteria underlying the typology in Figure 2, on the assumption that, at a more general level, both are based on the individualism-collectivism (or etatism) dimension. On this dimension at least three types of democratic community can be placed. The libertarian community is closest to the individualist pole, the socialist community to the collectivism pole, with the liberal community between the two. If we apply these criteria, the Anglo-American countries can be assumed to exhibit a tendency towards the libertarian community, Western European countries towards the liberal community, and the countries of Central and Eastern Europe towards the socialist community. The latter is likely to apply most strongly for the Slavic successor countries to the Soviet Union.

\subsection{Democratic Community}

Two questions are to be settled in the first step of the empirical analysis. First, the extent to which the societal communities in the countries under study are democratic, and, second, how marked the similarities or differences between these countries are. The analysis is guided by the expectations formulated in the previous section.

The criteria for a democratic community have been laid down as operational definitions (see Figure 1). With the exception of "mutual recognition as free and politically equal citizens", indicators of all the attributes of a democratic community are contained in the World Values Survey 1995-1999. The distributions of attitudes and behavioural dispositions measured by these indicators are shown in Table 3.

We will not interpret the empirical findings shown in Table 3 in any detail. ${ }^{2}$ They serve primarily as background information for the following systematic comparison to which we can refer as needed. Before we tackle this comparison, a few remarks on our methods are appropriate.

We describe and localise the countries under study by aggregating individual characteristics of citizens. The advantages and disadvantages of this strategy are well known, and they have been comprehensively discussed. Our approach differs from most in that we make a priori assumptions that are theoretically justified. On the one hand we define the democratic community in general and the types of democratic community on the basis of a number of specific characteristics. On the other hand, we determine which countries best

2 The indicators and indices are described in greater detail in Appendix 1. 
Table 3: Empirical Evidence of Citizen Support of a Set of Criteria for a Democratic Community

\begin{tabular}{|c|c|c|c|c|c|c|}
\hline \multirow[t]{3}{*}{ Countries } & \multicolumn{2}{|c|}{ Culture } & \multicolumn{2}{|c|}{ Structure } & \multicolumn{2}{|c|}{ Process } \\
\hline & DEMa) & AUTa) & PSC & CGI & VIO & LAW \\
\hline & $\%$ & $\%$ & $\%$ & $\%$ & $\%$ & $\%$ \\
\hline \multicolumn{7}{|c|}{ Anglo-American countries } \\
\hline USA & 88 & 5 & 35 & 27 & 83 & 98 \\
\hline Australia & 83 & 6 & 30 & 23 & 85 & 97 \\
\hline New Zealand & 88 & 3 & 14 & 11. & 87 & 95 \\
\hline \multicolumn{7}{|c|}{ Western European countries } \\
\hline Norway & 93 & 3 & 67 & 60 & 91 & 97 \\
\hline Sweden & 93 & 5 & 27 & 39 & 88 & 93 \\
\hline Finland & 75 & 10 & 34 & 23 & 91 & 94 \\
\hline West Germany & 93 & 1 & 40 & 20 & 85 & 88 \\
\hline Spain & 92 & 8 & 31 & 25 & 76 & 97 \\
\hline \multicolumn{7}{|c|}{ Central European countries } \\
\hline East Germany & 91 & 2 & 38 & 12 & 85 & 90 \\
\hline Czech Republic & 88 & 4 & 33 & 18 & 80 & 86 \\
\hline Slovakia & 88 & 4 & 36 & 30 & 73 & 82 \\
\hline Hungary & 83 & 5 & 32 & 30 & 80 & 89 \\
\hline Slovenia & 82 & 6 & 28 & 24 & 70 & 85 \\
\hline Croatia & 95 & 13 & 45 & 38 & 87 & 74 \\
\hline \multicolumn{7}{|l|}{ Baltic countries } \\
\hline Estonia & 85 & 6 & 30 & 36 & 83 & 91 \\
\hline Latvia & 79 & 8 & 24 & 19 & 83 & 83 \\
\hline Lithuania & 87 & 15 & 29 & 23 & 76 & 90 \\
\hline \multicolumn{7}{|c|}{ South-Eastern European countries (mainly Orthodox) } \\
\hline Yugoslavia & 88 & 10 & 24 & 29 & 74 & 92 \\
\hline Romania & 89 & 22 & 11 & 16 & 77 & 94 \\
\hline Bulgaria & 80 & 19 & 36 & 43. & 79 & 96. \\
\hline \multicolumn{7}{|c|}{ South-Eastern European countries (mixed-Muslim) } \\
\hline Macedonia & 73 & 15 & 21 & 16 & 79 & 89 \\
\hline Bosnia- & 87 & 26 & 32 & 57 & 72 & 97 \\
\hline Herzegovina & & & & & & \\
\hline Albania & 98 & 65 & 43 & 35 & 93. & 92 \\
\hline \multicolumn{7}{|c|}{ Eastern European countries } \\
\hline Russia & 51 & 20 & 7 & 16 & 82 & 85 \\
\hline Ukraine & 75 & 17 & 13 & 29 & 78 & 81 \\
\hline Belarus & 75 & 17 & 12 & 26 & 83 & 80 \\
\hline Moldova & 71 & 16 & 14 & 33 & 66 & 82 \\
\hline
\end{tabular}

DEM: Support of democratic rule; AUT: Support of autocratic Rule; PSC: Support of political system of one's own country; CGI: Confidence in governmental institutions; VIO: Illegitimacy of violence; LAW: Law abidingness. Cell entries are percent positive support.

a) The addition of both percentage can exceed 100 . There are respondents who equally support democratic and autocratic rules. 
represent the democratic community and its types. These are the benchmark countries of our analysis. We assume that all respondents can be described and related to the benchmark countries through a combination of the properties constitutive to the respective community. By using discriminant analysis as a statistical technique we are able to answer two questions. First, how important the specific characteristics (indicators) are in predicting the membership of a respondent in the predefined group on the one hand and in the undefined group on the other. Second, for every respondent from the undefined group, the probability of his belonging to the defined or known group can be determined.

The tables show several figures useful in assessing results. First, correlations of the variables with the discriminant function: the higher the correlation, the more important is the variable or the indicator for discriminating between citizens in the known group and those in the group of other countries. Second, eigenvalues and canonical correlations: both high eigenvalues and high canonical correlations mean that the two groups are well separated by the given set of variables. Third, group centroids are reported. These figures are simply average scores for respondents belonging to each of the predefined groups. Fourth, we show simplified classification results. Each respondent is allocated to a group according to his greatest probability - given the set of variables for the prediction. The share of correctly classified respondents is an indictor of the goodness of fit.

Discriminant analysis allows us to assign a probability of belonging to a group that is defined a priori to represent a certain theoretical category. We use this capability in our analysis. Although the initial score is allocated to the individual respondent, we use this variable in our analysis mainly to describe nation-states by averaging the respective information.

The standard against which we determine the extent to which the societal community in specific countries is democratic is a group of countries that undoubtedly represent such a community. The countries concerned are, first the United States and Australia, and, second, Sweden and West Germany. These are the benchmark democracies for the discriminant analysis. Table 4 shows how strongly the eight attributes of a democratic community distinguish between the benchmark democracies and the other countries. With one exception - "confidence in governmental institutions" - all correlations of the variables with the discriminant function are statistically significant. The highest correlations are in "support for autocracy" (-.799) at the cultural level and "law-abidingness" (.583) at the process level. 60 per cent of respondents were correctly classified on the basis of this weighted combination of characteristics. 
Table 4: Differentiation Between Benchmark Democracies and Other Countries

Democraciesa)

$\mathrm{r}^{\mathrm{b})}$

\section{Cultural level}

Support of democracy

Support of autocracy

\section{Structural level}

Support for current political system

Confidence in gov't institutions

Process level

Illegitimacy of violence

Law abidingness

Eigenvalue

Canonical correlation

\section{Group centroids}

Groups to classify

Democracies

Classification results

\begin{tabular}{lcc} 
& Group & 2 \\
& 1 & \\
1 Group to classify & .58 & .42 \\
2 Democracies & .32 & .68 \\
Correctly classified & 60 & \\
\hline a) Benchmark countries: USA, Australia, Sweden and West Germany & \\
b) Pooled within-group correlations between discriminating variables and canonical discriminant function. \\
c) Not significant at the .001 level.
\end{tabular}

However, our analysis is concerned with the categorisation and comparison of countries and groups of countries. For this purpose we have aggregated the results obtained at the individual level. Table 5 shows the mean of probability for respondents in a country to belong to the group of benchmark democracies as defined by the characteristics stated in Table 4. Countries are classified in terms of the geographical groups explained in the theoretical section. The name of each geographical group is given in italics over the countries, and the mean and standard deviations for these groups are also stated. The expectation formulated in the theoretical section relative to the geographical country groups postulates the following ordinal sequence in degrees of democratic community: (1) 
the Anglo-American and Western European countries; (2) the Central European countries; (3) the Baltic countries; (4) the South-Eastern European countries; (5) the Eastern European countries.

This assumption is essentially confirmed by empirical findings. The deviant group is the Baltic nations, which rank after the Orthodox South-Eastern European countries. However, the results for individual Baltic countries differ greatly. Whilst the mean for Estonia corresponds more or less to that for Slovenia and Croatia in Central Europe, Latvia and Lithuania trail behind the South-Eastern European Muslim countries. Estonia's distinctiveness can be attributed to the country's greater modernity in comparison with the other two Baltic nations (see Table 1) and to the high proportion of the population - in comparison with all the countries under study - with no religious ties (see Table 2).

By far the greatest misclassification of a country in a geographical group is Albania. Of all countries, Albania shows the lowest mean and thus the greatest distance to the benchmark democracies. The result cannot be explained with reference to the country classification criteria. Possibly the regime of Enver Hodscha plays a role, certainly one of the most totalitarian among comparable regimes in Europe.

As we expected, the Slavic successor countries to the Soviet Union, here termed Eastern European countries, show by far the lowest mean score of all regional groups (see Table 5). They thus correspond least to the benchmark democracies. However, a majority in Moldova, Belarus, and Ukraine also clearly favours democracy, while only a minority is in favour of autocracy (see Table 3). Relative distance from the benchmark democracies thus does not necessarily mean that the citizens of the country concerned do not form a democratic community. The relatively least support for democracy (51 per cent) and a relatively high support for autocracy ( 20 per cent) among Eastern European countries is to be found in Russia. Of all the countries under study, Russia, together with Albania, has the lowest mean score. These two countries are accordingly the least democratic as far as the attitudes and behaviours of their citizens are concerned.

Among the Anglo-American and Western European countries, two deviate relatively strongly from the others: Spain and, above all, Finland (see Table 5). In the case of Spain this is attributable above all to the below average rejection of violence as a political instrument, and in the case of Finland to the below average support for democracy (see Table 3). The explanation ex-post factum may be the tradition of violent confrontation in Spain and the geographical proximity and former dominance of Finland to Russia and the Soviet Union. Finland is the only country in Western Europe that belonged to an autocratic empire (Russia) for a longer period. These two deviant cases also explain most of the difference in the mean between the Anglo-American countries and the countries of Western Europe. 
Table 5: Closeness of Countries to the Benchmark Democracies

\begin{tabular}{|c|c|c|c|}
\hline Countries & Mean $^{\text {a) }}$ & $\mathrm{Sd}^{\mathrm{a})}$ & $\mathrm{Na)}$ \\
\hline Anglo-American countries & .552 & $(.118)$ & 3,749 \\
\hline $\mathrm{USA}^{\mathrm{b})}$ & .562 & $(.12)$ & 1,235 \\
\hline Australiab) & .538 & $(.12)$ & 1,726 \\
\hline New Zealand & .565 & $(.11)$ & 788 \\
\hline Western European countries & .536 & $(.123)$ & 4,494 \\
\hline Norway & .579 & $(.11)$ & 1,077 \\
\hline Sweden $\left.{ }^{b}\right)$ & .530 & $(.12)$ & 862 \\
\hline Finland & .493 & (.13) & 796 \\
\hline West Germanyb) & .551 & $(.11)$ & 896 \\
\hline Spain & .511 & $(.12)$ & 863 \\
\hline Central European countries & .497 & $(.135)$ & 4,980 \\
\hline East Germany & .539 & $(.12)$ & 888 \\
\hline Czech Republic & .512 & $(.13)$ & 935 \\
\hline Slovakia & .482 & (.13) & 868 \\
\hline Hungary & .512 & $(.13)$ & 494 \\
\hline Slovenia & .486 & $(.14)$ & 807 \\
\hline Croatia & .460 & $(.14)$ & 988 \\
\hline Baltic countries & .436 & $(.131)$ & 2,168 \\
\hline Estonia & .477 & $(.13)$ & 782 \\
\hline Latvia & .418 & $(.12)$ & 894 \\
\hline Lithuania & .403 & $(.12)$ & 492 \\
\hline $\begin{array}{l}\text { South-Eastern European countries (mainly } \\
\text { Orthodox) }\end{array}$ & .468 & $(.135)$ & 2,382 \\
\hline Yugoslavia & .494 & $(.13)$ & 1,013 \\
\hline Romania & .453 & $(.14)$ & 804 \\
\hline Bulgaria & .444 & $(.12)$ & 565 \\
\hline $\begin{array}{l}\text { South-Eastern European countries (mixed- } \\
\text { Muslim) }\end{array}$ & .405 & $(.133)$ & 2,091 \\
\hline Macedonia & .429 & $(.12)$ & 589 \\
\hline Bosnia-Herzegovina & .436 & $(.13)$ & 966 \\
\hline Albania & .322 & $(.10)$ & 536 \\
\hline Eastern European countries & .374 & $(.127)$ & 3,796 \\
\hline Russia & .362 & $(.13)$ & 1,011 \\
\hline Ukraine & .380 & $(.13)$ & 1,008 \\
\hline Belarus & .382 & $(.12)$ & 1,054 \\
\hline Moldova & .373 & $(.13)$ & 723 \\
\hline Total & .477 & $(.12)$ & 23,660 \\
\hline Eta2 & .228 & & \\
\hline
\end{tabular}

a) Mean = Mean membership probability of respondents belonging to the group of benchmark democracies, defined by the set of eight characteristics of democratic community; $\mathrm{Sd}=$ Standard deviation; $\mathrm{N}=$ Number of cases.

b) Benchmark democracies. 
For the further analysis of the democratic community we made two simplifications in comparison with the discriminant analysis. First, we restricted ourselves to the three characteristics: "support of democracy", "support of autocracy", and "law-abidingness". We thus leave out attitudes to the political system in the respondents' own country, the theoretical status of which is not fully clear (see section 2). The three attributes taken into account, are, however, also those that most clearly distinguish the group of benchmark democracies from the group of other countries (see Table 4). Second, we make no a priori assumption in the form of a reference group (benchmark democracies). We localise the countries in a two-dimensional space (see Figure 4). The one dimension is the proportion of respondents that clearly support democracy while rejecting autocracy. These respondents are termed "solid democrats" (Klingemann 1999). The second dimension is the proportion of respondents that exhibit differing degrees of law-abidingness.

The countries are relatively widely scattered in the two-dimensional space. Although there is a significant linear relationship between the two dimensions, it is not very marked $\left(\mathrm{R}^{2}=.12\right)$. Nevertheless, certain patterns can be identified that correspond to the results of the discriminant analysis. Countries with a pronounced democratic community are located in the top right-hand area of the space, the Anglo-American countries and some Western European countries. Of the Western European countries, Spain and West Germany deviate most. Finland and Spain exhibit above average law-abidingness and an only average proportion of solid democrats. With West Germany exactly the opposite applies.

The left-hand bottom part of the space is occupied by countries whose societal community can be described as least democratic. Here we find the same countries that scored lowest in the discriminant analysis: the Eastern European countries and Albania. Combining dear support for democracy and rejection of democracy produces an even more marked result. In all five countries (Russia, Ukraine, Belarus, Moldova, Albania) solid democrats are a minority of less than 25 per cent. At the same time, the level of law-abidingness is below average. The Central European countries (Czech Republic, Slovakia, and Hungary), although spatially somewhat apart from the North American and Western European countries, are still much closer to them than to the Eastern European countries and Albania. This finding, too, conforms to the discriminant analysis. 
Figure 4: Location of Countries in a Two-Dimensional Space of Democratic Community

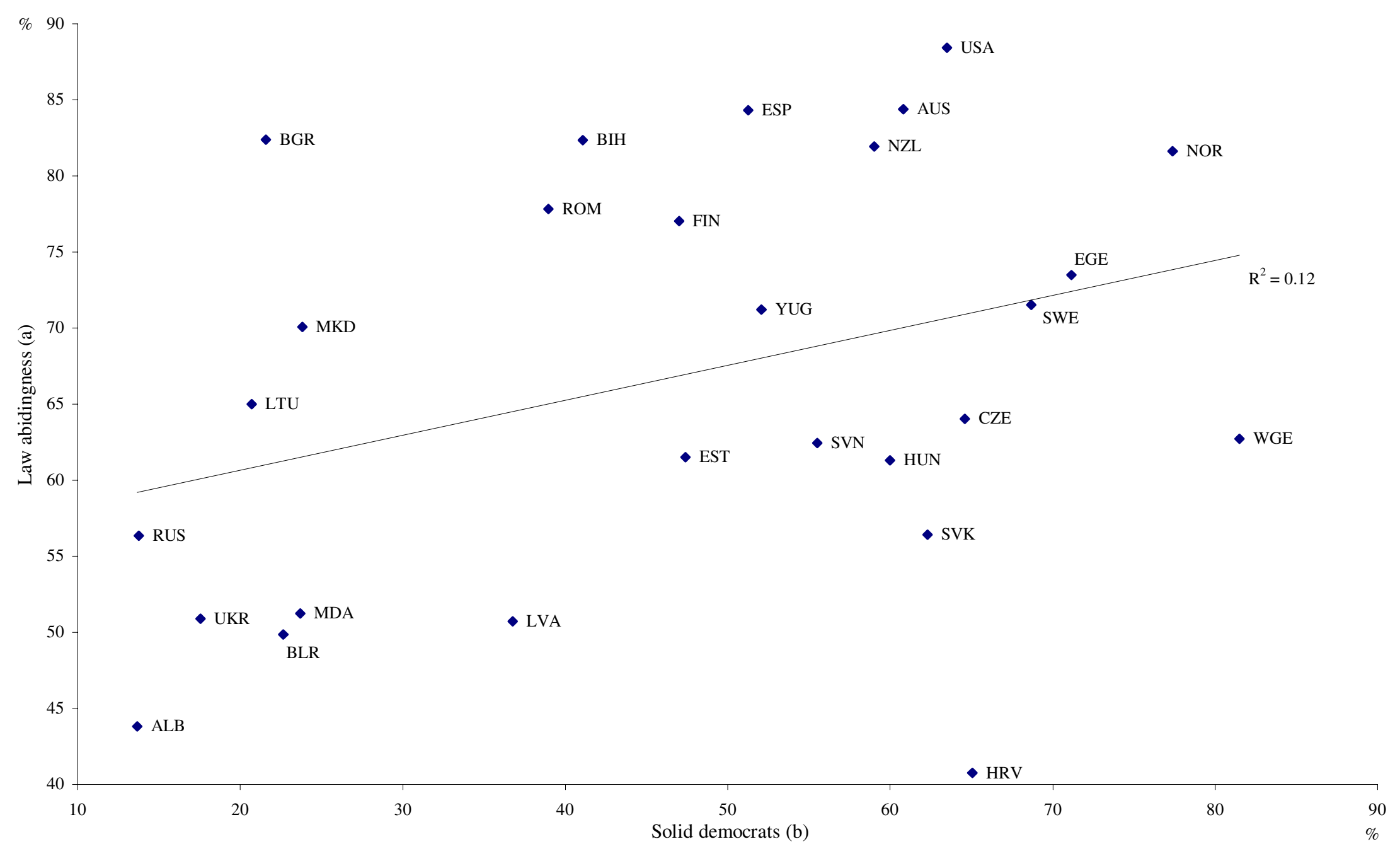

(a) Percentage of people with high degree of law abidingness (see Appendix 1); (b) Percentage of people who support democratic rule and at the same time reject autocratic rule. 


\subsection{Types of Democratic Community}

A democratic community is characterised by its members exhibiting attitudes and behaviours that meet the minimum demands of a democracy. However, a democracy can be differently realised and structured. Citizens can have differing normative ideas about this. On the basis of the democracy theory discussion, we have distinguished four normative models of democracy and the corresponding four types of democratic community (see Figure 2). Having in the preceding section empirically analysed the similarities and differences between countries with regard to the democratic community, we proceed in this section to do the same for the types of democratic community.

In Figure 3 the four types of democratic community are described in terms of characteristics that are theoretically relevant and for which indicators are available in the World Values Survey 1995-1999. The distributions of the specific attitudes and behaviours are shown in Tables 6.1 and 6.2. The detailed description of the indicators and indices is to be found in the Appendix 2. In this case, too, we will not deal with the distributions in detail but turn directly to the comparison between countries.

In this comparison we proceed as with the democratic community. The statistical method used is discriminant analysis, and we define benchmark countries as the point of reference for classifying individual countries. As explained in the theoretical section 2, our definition of benchmark democracies draws primarily on the study by Lipset (1996) and a follow-up empirical analysis (Fuchs and Klingemann 2000). According to these studies, the United States is to be considered a libertarian democracy with republican elements. For the sake of simplicity, we take recourse in Table 7 and the following tables and figures only to the characterisation as libertarian democracy. Australia has structural properties similar to those of the United States (see Tables 1 and 2) and exhibits similar political attitudes and behaviours. In our analysis, Australia - in addition to the United States therefore represents the libertarian type of democracy, and the two countries form the corresponding benchmark group.

In contrast to the individualism of the United States, Western European countries have a pronounced etatist tradition. This was realised in the development of welfare states, whose functions include ensuring the greatest possible equality of opportunity for individuals competing in the markets. These welfare states correspond to the liberal model of democracy, and a societal community with the relevant attitudes and behaviours is therefore to be termed a liberal community. The benchmark countries we have chosen to represent this liberal type of community are Sweden and West Germany. Both are indubitably welfare states, but they have developed different forms (Roller 2000). By 
taking these two countries into account, the relevant spectrum of Western European welfare states and thus of Western European liberal democracies has been covered.

Table 6.1: Citizen Support of Different Types of Democratic Community at Cultural Level

\begin{tabular}{|c|c|c|c|c|c|}
\hline \multirow[t]{2}{*}{ Countries } & \multicolumn{5}{|c|}{ Culture } \\
\hline & $\begin{array}{c}\text { SRE } \\
\%\end{array}$ & $\begin{array}{c}\text { SOL } \\
\%\end{array}$ & $\begin{array}{c}\text { TRU } \\
\%\end{array}$ & $\begin{array}{c}\text { WET } \\
\%\end{array}$ & $\begin{array}{c}\text { ETO } \\
\%\end{array}$ \\
\hline \multicolumn{6}{|c|}{ Anglo-American countries } \\
\hline USA & 66 & 21 & 35 & 68 & 9 \\
\hline Australia & 47 & 29 & 40 & 61 & 18 \\
\hline New Zealand & 45 & 34 & 47 & 61 & 21 \\
\hline \multicolumn{6}{|c|}{ Western European countries } \\
\hline Norway & 37 & 19 & 65 & 42 & 22 \\
\hline Sweden & 67 & 49 & 57 & 49 & 40 \\
\hline Finland & 42 & 41 & 48 & 57 & 20 \\
\hline West Germany & 41 & 75 & 40 & 25 & 45 \\
\hline Spain & 24 & 67 & 29 & 55 & 23 \\
\hline \multicolumn{6}{|c|}{ Central European countries } \\
\hline East Germany & 19 & 86 & 24 & 33 & 35 \\
\hline Poland & 36 & 61 & 17 & 32 & 5 \\
\hline Czech Republic & 23 & 51 & 27 & 43 & 30 \\
\hline Slovak Republic & 14 & 52 & 26 & 45 & 17 \\
\hline Hungary & 12 & 82 & 22 & 43 & 13 \\
\hline Slovenia & 24 & 53 & 15 & 58 & 20 \\
\hline Croatia & 11 & 62 & 23 & 54 & 22 \\
\hline \multicolumn{6}{|l|}{ Baltic countries } \\
\hline Estonia & 16 & 56 & 21 & 57 & 5 \\
\hline Latvia & 17 & 66 & 24 & 52 & 8 \\
\hline Lithuania & 24 & 74 & 21 & 33 & 3 \\
\hline \multicolumn{6}{|c|}{ South-Eastern European countries (mainly Orthodox) } \\
\hline Yugoslavia & 16 & 65 & 29 & 45 & 4 \\
\hline Romania & 31 & 63 & 18 & 63 & 6 \\
\hline Bulgaria & 22 & 71 & 24 & 52 & 14 \\
\hline \multicolumn{6}{|c|}{ South-Eastern European countries (mixed-Muslim) } \\
\hline Macedonia & 16 & 74 & 7 & 35 & 2 \\
\hline Bosnia-Herzegovina & 17 & 59 & 27 & 60 & 3 \\
\hline Albania & 14 & 62 & 24. & 88 & 2 \\
\hline \multicolumn{6}{|c|}{ Eastern European countries } \\
\hline Russia & 16 & 79 & 23 & 48 & 3 \\
\hline Ukraine & 14 & 76 & 29 & 43 & 3 \\
\hline Belarus & 17 & 70 & 23 & 52 & 4 \\
\hline Moldova & 14 & 75 & 22 & 54 & 3 \\
\hline
\end{tabular}

SRE: Self-responsibility; SOL: Solidarity; TRU: Trust in others; WET: Work ethic; ETO: Ethic tolerance. Cell entries are percent positive support (for details compare Appendix 2). 
Table 6.2: Citizen Support for Different Types of Democratic Community at Structural and Process Levels

\begin{tabular}{|c|c|c|c|c|}
\hline \multirow[t]{2}{*}{ Countries } & \multicolumn{2}{|c|}{ Structure } & \multicolumn{2}{|c|}{ Process } \\
\hline & $\begin{array}{c}\text { PRO } \\
\%\end{array}$ & $\begin{array}{c}\text { MAN } \\
\%\end{array}$ & $\begin{array}{c}\text { PMO } \\
\%\end{array}$ & $\begin{array}{c}\text { CIV } \\
\%\end{array}$ \\
\hline \multicolumn{5}{|c|}{ Anglo-American countries } \\
\hline USA & 74 & 55 & 52 & 52 \\
\hline Australia & 62 & 51 & 45 & 45 \\
\hline New Zealand & 52 & 64 & 41. & 35 \\
\hline \multicolumn{5}{|c|}{ Western European countries } \\
\hline Norway & 46 & 34 & 43 & 25 \\
\hline Sweden & 48 & 36 & 41 & 24 \\
\hline Finland & 59 & 35 & 17 & 12 \\
\hline West Germany & 61 & 30 & 55 & 25 \\
\hline Spain & 34 & 37 & 17 & 13 \\
\hline \multicolumn{5}{|c|}{ Central European countries } \\
\hline East Germany & 37 & 29 & 47 & 16 \\
\hline Poland & 31 & 15 & 27 & 0 \\
\hline Czech Republic & 38 & 42 & 27 & 7 \\
\hline Slovak Republic & 23 & 21 & 28 & 6 \\
\hline Hungary & 40 & 24 & 24 & 9 \\
\hline Slovenia & 49 & 22 & 14 & 8 \\
\hline Croatia & 75 & 34 & 24 & 13 \\
\hline \multicolumn{5}{|l|}{ Baltic countries } \\
\hline Estonia & 33 & 40 & 26 & 3 \\
\hline Latvia & 36 & 37 & 25 & 5 \\
\hline Lithuania & 47 & 38 & 25 & 2 \\
\hline \multicolumn{5}{|c|}{ South-Eastern European countries (mainly Orthodox) } \\
\hline Yugoslavia & 42 & 25 & 21 & 4 \\
\hline Romania & 55 & 37 & 21 & 9 \\
\hline Bulgaria & 40 & 27 & 23 & 2 \\
\hline \multicolumn{5}{|c|}{ South-Eastern European countries (mixed-Muslim) } \\
\hline Macedonia & 58 & 37 & 21 & 8 \\
\hline Bosnia-Herzegovina & 49 & 25 & 37 & 20 \\
\hline Albania & 78 & 48 & 19 & 7 \\
\hline \multicolumn{5}{|c|}{ Eastern European countries } \\
\hline Russia & 14 & 16 & 23 & 3 \\
\hline Ukraine & 32 & 23 & 25 & 1 \\
\hline Belarus & 25 & 20 & 38 & 1 \\
\hline Moldova & 20 & 23 & 23 & 5 \\
\hline
\end{tabular}

PRO: Private ownership; MAN: Management of enterprise; PMO: Political motivation; CIV: Civic engagement.

Cell entries are percent positive support (for details compare Appendix 2). 
The correlations of the indicators of the discriminant function in Table 7 show how strongly the individual characteristics distinguish between the benchmark countries and the other countries. In the case of libertarian democracy, the highest correlations are for "selfresponsibility" and "solidarity with the disadvantaged", as well as "civic engagement". The first two characteristics are also those with which a libertarian democracy can most strongly be identified in accordance with our theoretical assumption (see Figures 2 and 3), and "civic engagement" is typical of republican democracies (see Figure 3). For liberal democracy, the highest correlations are for "self-responsibility" and "ethic tolerance".

Table 7: Differentiation Between Benchmark Types of Democracies and Other Countries

\begin{tabular}{cc} 
Type of democracy \\
Libertarian democracya) & Liberal democracyb) \\
$\mathrm{r}^{\mathrm{c})}$ & $\mathrm{r}^{\mathrm{c})}$ \\
\hline
\end{tabular}

Cultural level

Self-responsibility

.464

.513

Solidarity with the disadvantaged

$-.504$

Trust in others

.114

Work ethic

.178

$-.226$

Ethic tolerance

.012

.722

Structural level

Private ownership

.354

Management of enterprise (owners)

.286

Process level

Political motivation

.232

.786

Civic engagement

Eigenvalue

.294

.096

Canonical correlation

.476

.296

Group centroids

Group to classify

$-.075$

Liberal democracies

1.522

1.274

Classification results

1 Group to classify

2 Liberal democracies

1
84
30

Group

Group

Correctly classified

30

16

70

76

23

24

82

76

Benchmark countries: a) United States and Australia; b) Sweden and West Germany.

c) Pooled within-group correlations between discriminating variables and canonical discriminant functions. 
These characteristics, too, are to be found in the description of the liberal community in Figure 3. The proportion of correctly classified respondents is much higher for these two types of democratic community than for the democratic community in general. For "libertarian democracy" the figure is 82 per cent, and for "liberal democracy" 76 per cent. This indicates that the difference between the reference group and the group of other countries is relatively large. We will be dealing with this in greater detail.

The socialist community has not been included in the comparative analysis. The reason is a simple one: there is no Western country that can plausibly represent this type of community. There is also no Western country that represents the republican community in a "pure" form. However, the United States and Australia also exhibit some republican properties. Although the benchmark group composed by these two countries predominantly represents a libertarian community, it has additional attributes.

In contrast to the democratic community in general, there are considerable differences between countries with regard to the type of democratic community. We will deal first with the libertarian community. Three gaps are identifiable between groups of countries (see Table 8). The first is between the Anglo-American and the Western European countries. For the first the mean is .656 and for the second .376. Since the Western European countries still have the highest mean of the European groups, the difference between Anglo-America and Europe posited by Lipset (1996) is impressively confirmed. Within the European countries, however, there are still substantial differences. The next gap in mean ranking is between Western European countries (.376) and Muslim SouthEastern countries (.282). Right at the end of the scale come the Baltic and Eastern European countries. The mean for both groups of countries is lower than .200. The democratic communities in Europe can thus definitively not be considered libertarian but at least liberal (Western European countries), if not even socialist. There are some striking deviations within groups of countries. Among Western European countries Spain and among Central European countries Hungary have a markedly lower mean than the other countries in their groups. And among the Muslim South-Eastern European countries, Bosnia-Herzegovina has by far the highest mean. This relatively greater proximity of Bosnia-Herzegovina to the benchmark democracies is, however, attributable less to the libertarian characteristics of the two countries that constitute the group than to the communitarian attribute of moral rigorism (see Table 6.1).

As the correlations of the liberal community characteristics with the discriminant function show (see Table 7), "self-responsibility" (.513) and especially "ethic tolerance" (.722) distinguish most clearly between the benchmark countries and the others. By the first (self-responsibility), a liberal community distinguishes itself above all from a socialist community. Thus, the results of the discriminant analysis do not inevitably fit the 
Table 8: Closeness of Countries to Liberal and Libertarian Types of Democracy

\begin{tabular}{|c|c|c|c|c|c|c|}
\hline \multirow[t]{2}{*}{ Countries } & \multicolumn{3}{|c|}{ Libertarian democracya) } & \multicolumn{3}{|c|}{ Liberal democracyb) } \\
\hline & Meanc) & $\mathrm{Sd}^{\mathrm{c})}$ & $\mathrm{N}^{\mathrm{c})}$ & Meanc) & $\mathrm{Sd}^{\mathrm{c})}$ & $\mathrm{N}^{\mathrm{c})}$ \\
\hline \multicolumn{7}{|l|}{ Anglo-American } \\
\hline USA & .752 & $(.27)$ & 1,016 & .426 & $(.26)$ & 1,016 \\
\hline Australia & .621 & $(.31)$ & 1,528 & .455 & $(.27)$ & 1,528 \\
\hline New Zealand & .580 & $(.29)$ & 578 & .473 & $(.25)$ & 578 \\
\hline \multicolumn{7}{|l|}{ Western European } \\
\hline countries & .376 & $(.28)$ & 3,652 & .524 & (.27) & 3,652 \\
\hline Norway & .470 & $(.28)$ & 970 & .494 & (.24) & 970 \\
\hline Sweden & .431 & $(.28)$ & 662 & .682 & $(.21)$ & 662 \\
\hline Finland & .334 & $(.26)$ & 708 & .424 & (.24) & 708 \\
\hline West Germany & .360 & $(.29)$ & 604 & .657 & $(.26)$ & 604 \\
\hline Spain & .251 & $(.25)$ & 708 & .406 & $(.27)$ & 708 \\
\hline \multicolumn{7}{|l|}{ Central European } \\
\hline countries & .240 & $(.24)$ & 4,317 & .380 & $(.25)$ & 4,317 \\
\hline East Germany & .224 & $(.23)$ & 687 & .505 & $(.28)$ & 687 \\
\hline Czech Republic & .263 & $(.24)$ & 794 & .413 & $(.23)$ & 794 \\
\hline Slovakia & .199 & $(.20)$ & 834 & .331 & $(.22)$ & 834 \\
\hline Hungary & .184 & $(.20)$ & 467 & .340 & $(.23)$ & 467 \\
\hline Slovenia & .277 & $(.25)$ & 731 & .330 & (.24) & 731 \\
\hline Croatia & .274 & $(.25)$ & 804 & .360 & $(.24)$ & 804 \\
\hline Baltic countries & .191 & $(.20)$ & 2,227 & .268 & $(.19)$ & 2,227 \\
\hline Estonia & .200 & $(.20)$ & 761 & .247 & (.18) & 761 \\
\hline Latvia & .192 & $(.20)$ & 844 & .290 & (.19) & 844 \\
\hline Lithuania & .179 & $(.18)$ & 622 & .262 & $(.19)$ & 622 \\
\hline \multicolumn{7}{|l|}{ South-Eastern } \\
\hline \multicolumn{7}{|l|}{ European countries } \\
\hline Yugoslavia & .180 & $(.19)$ & 1,073 & .252 & $(.20)$ & 1,073 \\
\hline Romania & .305 & $(.25)$ & 819 & .296 & $(.22)$ & 819 \\
\hline Bulgaria & .189 & $(.19)$ & 488 & .358 & $(.23)$ & 488 \\
\hline \multicolumn{7}{|l|}{ South-Eastern } \\
\hline \multicolumn{7}{|l|}{ European countries } \\
\hline Macedonia & .223 & $(.22)$ & 627 & .240 & (.18) & 627 \\
\hline Bosnia-Herzegovina & .321 & $(.29)$ & 917 & .267 & (.19) & 917 \\
\hline Albania & .287 & $(.29)$ & 649 & .249 & $(.17)$ & 649 \\
\hline \multicolumn{7}{|l|}{ Eastern European } \\
\hline countries & .143 & $(.16)$ & 4,719 & .247 & (.19) & 4,719 \\
\hline Russia & .136 & $(.16)$ & 1,294 & .251 & $(.25)$ & 1,294 \\
\hline Ukraine & .134 & (.14) & 1,381 & .256 & $(.20)$ & 1,381 \\
\hline Belarus & .146 & $(.15)$ & 1,255 & .264 & (.19) & 1,255 \\
\hline Moldova & .168 & $(.20)$ & 789 & .197 & (.17) & 789 \\
\hline Total & .297 & $(.23)$ & 22,610 & .352 & $(.22)$ & 22,610 \\
\hline Eta2 & .22 & - & - & .09 & - & - \\
\hline
\end{tabular}

a) Libertarian democracy: benchmark countries USA and Australia.

b) Liberal democracy: benchmark countries Sweden and West Germany.

c) Mean = Mean membership probability of respondents belonging to the group of benchmark democracies, defined by the set of nine characteristics; $\mathrm{Sd}=$ Standard deviation; $\mathrm{N}=$ Number of cases. 
libertarian-liberal-socialist continuum. In the liberal community, too, there are very clear differences between groups of countries. Also in keeping with theoretical expectations, Western European countries most strongly represent the liberal community (mean: .524). The Anglo-American and Central European countries follow after clear intervals, .449 and .380 respectively. The most striking difference is apparent between the Central European countries and the other groups. Among these other groups of countries, the Orthodox South-Eastern European countries have the relatively highest mean (.289) and the Eastern European countries the relatively lowest (.247). As far as the liberal community is concerned, the major cultural dividing line suggested by Huntington (1996) does exist, separating the Western-Christian civilisation (including Central Europe) from the Orthodox-Muslim civilisation in Eastern Europe.

Since characteristics that can relate to other types have been included in the two discriminant analyses on libertarian and liberal democracy, we omit characteristics that are theoretically quite unambiguous from the following considerations. In Figure 5, countries are localised in a two-dimensional space mapping the proportion of citizens with a strong sense of self-responsibility and those with a strong sense of solidarity. The regression line shown in the figure represents the underlying libertarian-liberal-socialist continuum: strong self-responsibility and weak solidarity characterise a libertarian community, and, vice versa, a socialist community is characterised by strong solidarity and weak selfresponsibility, with the liberal community located between the two. The variance of no less than 45 per cent explained by the regression shows that the assumption of this underlying continuum is justified. If we take the 50 per cent threshold in each case to ensure better orientation in the spatial classification of countries, the only country that simultaneously scores high on self-responsibility and low on solidarity is the United States. Accordingly, the United States is by far the most libertarian community, and "American exceptionalism" (Lipset 1996) is clearly in evidence. Surprisingly, an above average proportion of Swedes have a pronounced sense of self-responsibility, while evincing much greater solidarity than Americans. This high degree of Swedes' sense of self-responsibility can be ascribed to two aspects. First, the measurement of "self-responsibility" relates to the respective country's status quo (see Appendix 2). Second, Swedes place a relatively strong emphasis on the value of self-responsibility ideologically, thus justifying the welfare state in part with the ability for self-responsibility (Rothstein 1998).

In the upper left-hand part of the space, which is defined by strong solidarity and weak self-responsibility, thus delimiting a socialist community, we find all the countries from Central and Eastern Europe - plus Spain as the only Western European country. Within this cluster of countries, no further differentiation by geographical region is possible. For example, two of the countries we have assigned to Central Europe - Hungary and East 
Figure 5: Location of Countries on the Libertarian-Liberal-Socialist Dimension

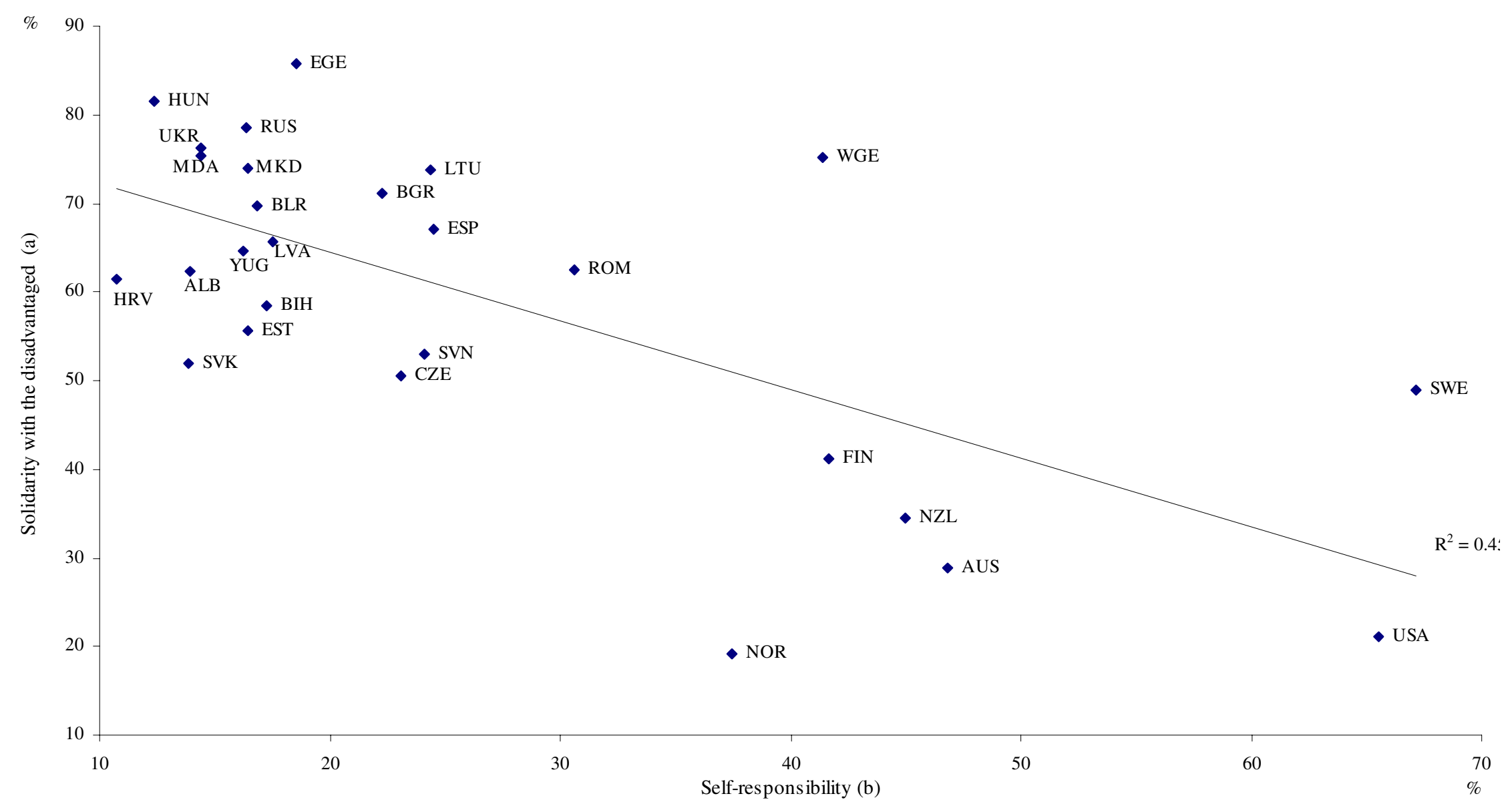

(a) Proportion of respondents with high solidarity (see Appendix 2); (b) Proportion of respondents with high self-responsibility (see Appendix 2) 
Germany - together with the Eastern European countries Russia, Ukraine, and Moldova, form the outermost fringe of the cluster, thus representing the relatively most socialist communities. In contrast, two Central European countries - Slovenia and the Czech Republic - together with Romania are gathered at the opposite fringe of the cluster in the direction of the Western countries. The countries deviating most from the regression line are West Germany and Norway. They are average on self-responsibility, but solidarity is below average in Norway and above average in West Germany.

The two dimensions in Figure 6 relate to the constitutive characteristics of a republican or civic community. A fundamental normative concept in this type of democratic community is that the individual and not government should bear primary responsibility for the individual's affairs (see Figure 2). The same is demanded by libertarians; but, in contrast to libertarians, republicans do not assume that collective goals can be attained only indirectly through the mechanisms of the market. They stress active co-operation between citizens to realise common projects (Putnam 1993; Fukuyama 1999). The resource on which such co-operation can draw is termed social capital. Social capital consists primarily in shared values and norms of reciprocity and co-operation. A consequence of the mutual assumption that such values and norms apply, and of experience with relevant action is trust or confidence in the other members of the community. Trust in others is therefore frequently used as an indicator of the social capital of a community. Co-operative values and norm orientations induce citizens to participate actively in voluntary associations, and this in its turn stabilises the social capital. Putnam (1993) therefore refers to civil or voluntary associations as "social structures of co-operation". In Figure 6, active participation by citizens in two or more voluntary associations is termed "civic engagement".

The link between "civic engagement" and "trust in others" that Putnam posits is controversial. As the regression analysis shows $\left(\mathrm{R}^{2}=.344\right)$ this assumption is confirmed by our data at least at the aggregate level of the countries under study. The classification of countries in the two-dimensional space of a republican community reveals a marked difference between Anglo-American and Western European countries on the one hand and the countries from Central and Eastern Europe on the other. The latter show less trust in others and less civic engagement. The only Western European country in the group is Spain. Taking the analysis results of this section for Central and Eastern Europe as a whole, we find a positive and a negative aspect: they relatively clearly represent a socialist community and just as clearly do not represent a republican community. 
Figure 6: Location of Countries in a Two-Dimensional Space of Republican Community

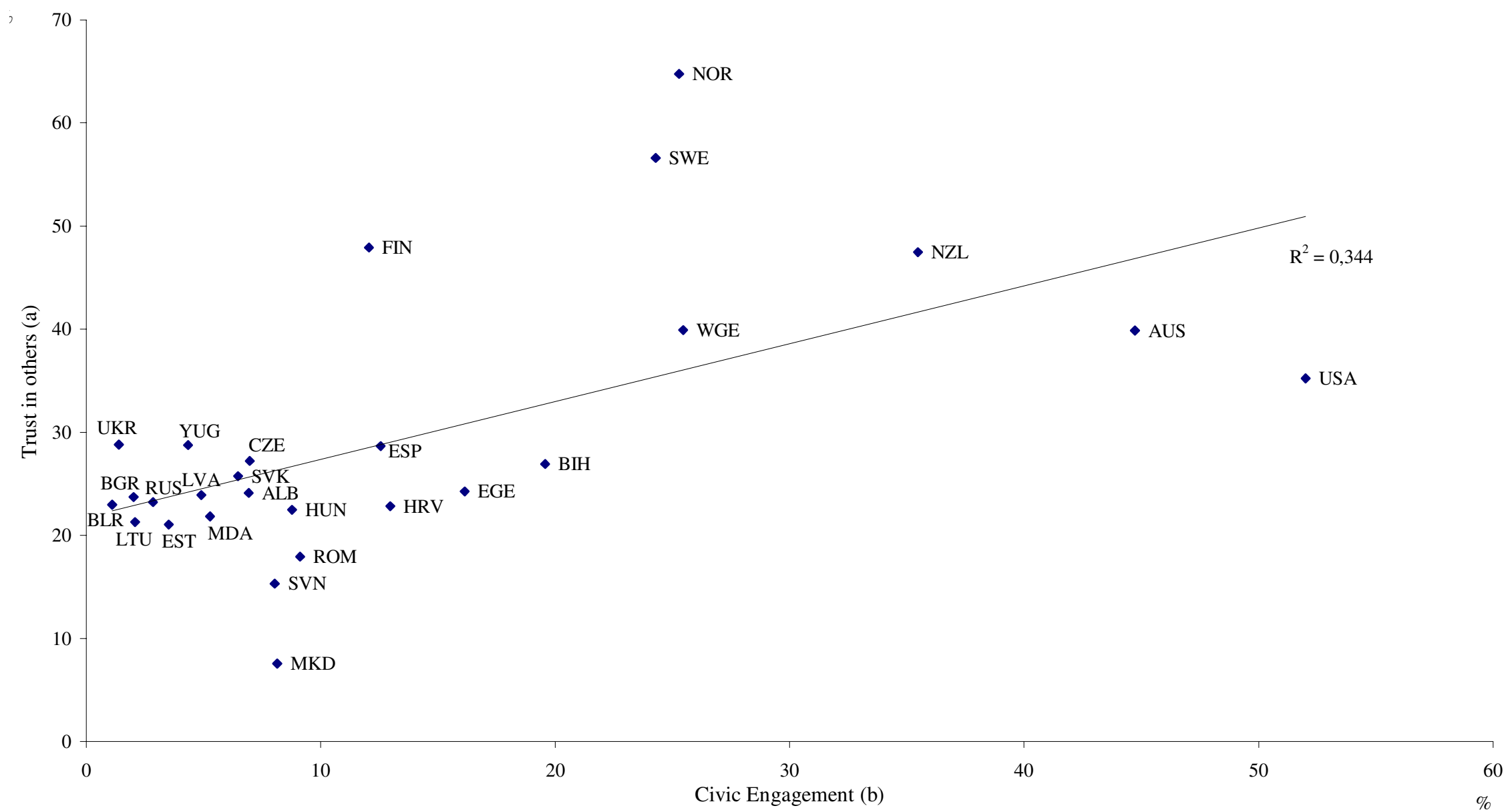

(a) Percentage of respondents who trust in other people (see Appendix 2); (b) Percentage of respondents who are active members in two or more voluntary associations (see Appendix 2). 
Among the Anglo-American and Western European countries, there is none that exhibits both strong confidence in others and strong civic engagement. Thus, we cannot identify a "pure" case of a republican community. Two configurations among these countries are evident. First, the two Nordic countries Norway and Sweden with an average level of civic engagement and a high level of trust in others, and, second, the two Anglo-American countries Australia and the United States with an average level of trust in others and a high level of civic engagement.

\section{Summary and Conclusions}

Development towards a politically integrated and geographically more comprehensive Europe appears to be irreversible. But the general dynamic of development offer fundamental options that have yet to be decided. One is the extent of political integration through European institutions. The central issue is how strongly the competence to make binding decisions is to be transferred from the nation states to the supranational regime of the EU. Another is the matter of the eastern border, the question which countries should belong to the EU. This is the point of reference for our study. Besides economic aspects, the question of the eastward enlargement of the EU is of strategic importance for the formation of a European demos. Every institutional arrangement of the EU needs to be legitimated, and the more strongly the decisions of these institutions directly impact the life world of the citizen, the greater is the need for legitimation. The addressee of this legitimation of a European regime and European politics is a European demos. For legitimation to be successful, a merely formal demos is presumably insufficient. Over and above legally defined membership, it should constitute a political community with a collective identity citizens can subjectively attribute to themselves and with which they can identify.

We proceed from two premises. First, that the collective identity of the European demos is grounded in subjectively perceived commonality in political values and behaviours; second, that objectively demonstrable commonality in both regards provides the potential for the formation of a collective identity. Against this background, we have attempted to answer two questions. First, the extent to which political values and behaviours are shared by the citizens of European countries; second, the extent to which there are systematic differences between Western, Central, and Eastern Europe, and where possible cultural borders lie. The most important results of our analysis can be summed up as follows.

Regardless of what institutional form the regime of the EU will ultimately take, it will be a democratic form of government. Moreover, one of the key criteria for a country to join 
the EU is that it has a stable democracy. However, a democracy can function and survive only if the demos as the ultimate sovereign also exhibits appropriate values and behaviours. In a first step, we have therefore empirically determined the extent to which societal community in the countries under study can be described as democratic, and what differences there are between countries and groups of countries.

Differences are apparent between groups of countries, but - with one exception - they are not very pronounced. They can be mapped on a geographical west-east axis. The relatively most democratic communities are to be found in the Anglo-American and Western European countries. The countries in which the democratic community is least developed are the Muslim countries in South-Eastern Europe and the Eastern European countries. Leaving aside the Anglo-American countries and regressing the scores of individual countries for the democratic community on a geographical west-east axis, no less than 62 per cent of variance can be explained. In certain measure, this result is in keeping with Huntington's (1996) theory. However, in contrast to Huntington's assumptions, no threshold can be identified between West and East, only a continuous decline in the extent of a democratic community.

The exception mentioned above is concerned with the countries of Eastern Europe, and, in our parlance, this means the Slavic successor states to the Soviet Union plus Moldova (Russia, Ukraine, Belarus, Moldova). Albania also belongs to the group. In all these countries, "law-abidingness" is clearly below average, and in every case there are fewer than 25 per cent "solid democrats" among the citizenry (see Figure 4). According to our criteria, there is therefore, at least currently, no solid democratic community in these countries. Besides the longer-term factors we have mentioned (religion, empire, Leninist regime, and modernity), the party systems are presumably responsible for this result. In all these countries, the party system is shaped by parties that support at least the introduction of autocratic elements into the existing governmental system, if not the imposition of autocratic systems as a whole (Klingemann 2000; Klingemann and Hofferbert 2000). The democratic transformation of the party system, in addition to economic development, is therefore a structural prerequisite that could strengthen the democratic community in these countries.

Whilst there are relatively slight differences between the countries under study as regards the democratic community in general, this is far from being the case with the types of community. This is particularly clear if one considers the libertarian-liberal-socialist dimension. According to our analysis, the United States is indubitably a libertarian community. The vast majority of American citizens consider that not the state but the individual is responsible for his own life; at the same time solidarity with the disadvantaged is very weak (see Figure 5). All the countries of Central and Eastern Europe 
offer a contrast to the United States. In these countries strong self-responsibility is evinced by less than a third of citizens, and in most countries by even less than 20 per cent. A majority, however, exhibits strong solidarity with the disadvantaged. Thus, on the basis of these two characteristics, the countries of Central and Eastern Europe can be considered socialist communities.

The two other Anglo-American countries (Australia and New Zealand), as well as the Western European countries score between the United States and the Central and Eastern European countries on self-responsibility. On solidarity the figures are at a similarly low level as that of the United States, the only exception being West Germany. Overall, these countries can therefore be classified as liberal communities, which are, however, closer to the libertarian United States than to the socialist Central and Eastern European communities.

Following on from the studies by Putnam (1993) and Fukuyama (1999), we have operationalized the republican community by the two dimensions "civic engagement" and "trust in others". The classification of countries in the space defined by these two dimensions again shows a clear West-East difference. Most republican are the Anglo-American countries United States, Australia, and New Zealand. Decidedly not republican, in contrast, are the countries of Central and Eastern Europe. "Civic engagement" is weak, "trust in others" is weak. The strong etatist orientation among citizens in Central and Eastern Europe is thus complemented and accordingly still further stabilised by a lack of civic society elements.

The question of the eastward enlargement of the EU can be discussed and answered from a variety of standpoints. For example, economic or geo-political considerations can play a role. The perspective taken by our analysis is that of the implications of eastward enlargement for the development of a European demos. This, in turn, is the condition for a viable European democracy. The greater the differences are between countries, the lower is the potential for a European identity on which a European demos can base.

Our study identifies three substantial dividing lines. The first runs between America and Europe, as already posited by Lipset (1996). For our purposes, however, this is of secondary importance. The second divides Western Europe from Central and Eastern Europe. The countries in these two parts of Europe represent different types of democratic community. At this political cultural level, Huntington's (1996) thesis of a cultural dividing line within Europe is confirmed to a certain extent. According to the theoretical premises of our analysis, every eastward enlargement poses integration problems and increases the difficulty of constituting a European demos. The West-East difference we have described is concerned with differing types of democratic community. Between the countries of Europe there is little difference in the political values and behaviours that are 
essential to a democracy. The potential for Europeans in Western, Central, and Eastern Europe to consider each other as democrats, and to integrate this understanding in their collective identity is thus considerable.

The Slavic successor nations to the Soviet Union (Russia, Ukraine, Belarus, and Moldova) together with Albania are the exception. They cannot, at least not yet, be considered democratic communities, and in all the analyses we have conducted, they offer a serious contrast to the Western European countries and, to some extent, also to the countries in Central and Eastern Europe. This is the third dividing line we identify. Taking account only of political cultural points of view, the eastern border of the EU would have to be drawn before these countries. However, there is also reason to believe that democratic institutions may be supportive in creating a democratic community.

\section{Appendix 1}

\section{Criteria for a democratic community}

\section{Cultural level}

\section{Support of democratic rule}

Item 1 "I'm going to describe various types of political systems and ask what you think about each as a way of governing this country. For each one, would you say it is a very good, fairly good, fairly bad or very bad way of governing this country?"

"Having a democratic political system"

Item 2 "I'm going to read off some things that people sometimes say about a democratic political system. Could you please tell me if you agree strongly, agree, disagree or disagree strongly, after I read each one of them?"

"Democracy may have problems but it's better than any other form of government." Scores of the two items are added to form the index "Support of democratic rule". Scale values run from 2 "low support for democratic rule" to 8 "high support for democratic rule". Table 3 presents proportion of respondents with scale values 6-8. 


\section{Support of autocratic rule}

Item 1 "I'm going to describe various types of political systems and ask what you think about each as a way of governing this country. For each one, would you say it is a very good, fairly good, fairly bad or very bad way of governing this country?"

"Having a strong leader who does not have to bother with parliament and elections."

Item 2 "I'm going to describe various types of political systems and ask what you think about each as a way of governing this country. For each one, would you say it is a very good, fairly good, fairly bad or very bad way of governing this country?"

"Having the army rule."

Scores of the two items are added to form the index "Support of autocratic rule". Scale values run from 2 "low support of autocratic rule" to 8 "high support of autocratic rule". Table 3 presents proportion of respondents with scale values 6-8.

\section{Structural level}

\section{Support for current political system of own country}

Item 1 "People have different views about the system for governing this country. Here is a scale for rating how well things are going: 1 means very bad and 10 means very good."

"Where on this scale would you put the political system as it is today?"

Scale values run from 1 "very bad" to 10 "very good". Table 3 presents the proportion of respondents with scale values 6-10.

\section{Confidence in governmental institutions}

"I am going to name a number of organisations. For each one, could you tell me how much confidence you have in them: is it a great deal of confidence, quite a lot of confidence, not very much confidence or none at all?"

Item 1 "Political parties"

Item 2 "The government in ..."

Item 3 "Parliament"

Scores of the three items are added to form the index "Confidence in governmental institutions". Scale values run from 3 "low confidence" to 12 "high confidence". Table 3 presents proportion of respondents with scale values 8-12. 
Process level

5. Illegitimacy of violence

Item 1 "Here's one more statement. How strongly do you agree or disagree with it?" (agree strongly, agree, disagree, disagree strongly)

"Using violence to pursue political goals is never justified."

Scale values run from 1 "disagree strongly" to 4 "agree strongly". Table 3 presents proportion of respondents with scale values 3-4.

\section{Law abidingness}

"Please tell me for each of the following statements whether you think it can always be justified, never be justified, or something in between, using this card" (Interviewer: read out statements. Code one answer for each statement.)

Item 1 "Claiming government benefits to which you are not entitled."

Item 2 "Avoiding a fare on public transport."

Item 3 "Cheating on taxes if you have a chance."

Scores of the three items are added to form the index "Law abidingness". Scale values run from 3 "low degree of law abidingness" to 30 "high degree of law abidingness". Table 3 presents proportion of respondents with scale values 24-30.

\section{Appendix 2}

\section{Criteria of different types of democratic community}

\section{Cultural level}

\section{Self-responsibility}

Item 1 "Now I'd like you to tell me your views on various issues. How would you place your views on this scale? 1 means you agree completely with the statement on the left; 10 means you agree completely with the statement on the right; and if your views fall somewhere in between, you can choose any number in between." 
1 "The government should take more responsibility to ensure that everyone is provided for"

10 "People should take more responsibility to provide for themselves"

Scale values run from 1 "low self-responsibility" to 10 "high self-responsibility". Table 6.1 presents proportion of respondents with scale values 7-10.

2. Solidarity with the disadvantaged

Item 1 "Why in your opinion, are there people in this country who live in need? Here are two opinions: Which come closest to your view?"

1 "They are poor because of laziness and lack of will power."

2 "They are poor because society treats them unfairly."

Item 2 "In your opinion, do most poor people in this country have a chance of escaping from poverty, or is there very little chance of escaping?"

1 "They have a chance."

2 "here is very little chance."

Scores of the two items are added to form the index "solidarity with the disadvantaged" Scale values run from 2 "low solidarity" to 4 "high solidarity". Table 6.1 presents proportion of respondents with scale value 4 .

\section{Trust in others}

Item 1 "Generally speaking, would you say that most people can be trusted or that you can't be too careful in dealing with people?"

1 "Most people can be trusted."

0 "Can't be too careful, don't know, no answer."

Table 6.1 presents proportion of respondents with scale value 1 .

\section{Work ethic}

Item 1 "Now I'd like you to tell me your views on various issues. How would you place your views on this scale? 1 means you agree completely with the statement on the left; 10 means you agree completely with the statement on the right; and if your views fall somewhere in between, you can choose any number in between."

1 "Hard work doesn't generally bring success -- it's more a matter of luck and connections." 
10 "In the long run, hard work usually brings a better life."

Table 6.1 presents proportion of respondents with scale values 7-10 ("hard work").

\section{Ethic tolerance}

"Please tell me for each of the following statements whether you think it can always be justified, never be justified, or something in between, using this card."

Item 1 "Homosexuality"

Item 2 "Prostitution"

Item 3 "Abortion"

Item 4 "Divorce"

Scores of the four items are added to form the index "Ethic tolerance". Scale values run from 4 "low ethic tolerance" to 40 "high ethic tolerance". Table 6.1 presents proportion of respondents with scale values $29-40$.

\section{Structural level}

\section{Private ownership}

Item 1 "Now I'd like you to tell me your views on various issues. How would you place your views on this scale? 1 means you agree completely with the statement on the left; 10 means you agree completely with the statement on the right; and if your views fall somewhere in between, you can choose any number in between."

1 "Government ownership of business and industry should be increased."

10 "Private ownership of business and industry should be increased."

Table 6.2 presents proportion of respondents with scale values 7-10 ("private ownership").

\section{Management of enterprise}

Item 1 "There is a lot of discussion about how business and industry can be managed. Which of these four statements comes closest to your opinion?"

1 "The owners should run their business or appoint the managers."

0 "The owners and the employees should participate in the selection of managers;"

"The government should be the owner and appoint the managers;"

"The employees should own the business and should elect the managers." 
Table 6.2 presents proportion of respondents with scale value 1 .

Process level

\section{Political motivation}

Item 1 "Please say, for each of the following, how important it is in your life. Would you say ..."

"Politics"

is very important, rather important, not very important or not at all important?

Item 2 "How interested would you say you are in politics?"

very interested, somewhat interested, not very interested, not at all interested?

Scale values run from 2 "low motivation" to 8 "high motivation involvement". Table 6.2 presents proportion of respondents with scale values 6-8.

\section{Civic engagement}

"Now I am going to read off a list of voluntary organisations; for each one, could you tell me whether you are an active member, an inactive member or not a member of that type of organisation?"

Item 1 "Church or religious organisation"

Item 2 "Sport or recreation organisation"

Item 3 "Art, music or educational organisation"

Item 4 "Labour union"

Item 5 "Political party"

Item 6 "Environmental organisation"

Item 7 "Professional organisation"

Item 8 "Charitable organisation"

Item 9 "Any other voluntary organisation"

Scores of the nine items ("active membership") are added to form the index "Civic engagement". Scale values run from 0 "no civic engagement" to 9 "high civic engagement". Table 6.2 presents proportion of respondents with scale values 2-9. 


\section{References}

Barber, Benjamin R. (1984): Strong Democracy. Participatory Politics For a New Age, Berkeley: University of California Press.

Berry, Christopher J. (1989): The Idea of a Democratic Community, New York: St. Martin's Press.

Chapman, John W., and Ian Shapiro (eds.), (1993): Democratic Community. Nomos No. $X X X V$, New York: New York University Press.

Etzioni, Amitai (1993): The Spirit of Community: The Reinvention of American Society, New York: Touchstone, Simon \& Schuster.

Etzioni, Amitai (1996): The New Golden Rule. Community and Morality in a Democratic Society, New York: Basic Books.

Ferree, Myra Marx, William A. Gamson, Jürgen Gerhards, and Dieter Rucht (2000): Collective Actors and the Public Sphere. Abortion Discourse in the U.S. and Germany, Cambridge, Mass.: Cambridge University Press (forthcoming).

Fuchs, Dieter (1999a): "Soziale Integration und politische Institutionen in modernen Gesellschaften," in: Jürgen Friedrichs and Wolfgang Jagodzinski (eds.): Soziale Integration. Sonderheft 39 der Kölner Zeitschrift für Soziologie und Sozialpsychologie, Opladen: Westdeutscher Verlag, pp. 127-178.

Fuchs, Dieter (1999b): “The Democratic Culture of Germany," in: Pippa Norris (ed.): Critical Citizens. Global Support for Democratic Government, Oxford: Oxford University Press, pp. 123-145.

Fuchs, Dieter (2000): "Die demokratische Gemeinschaft in den USA und in Deutschland," in: Jürgen Gerhards (ed.): Die Vermessung kultureller Unterschiede. USA und Deutschland im Vergleich, Opladen: Westdeutscher Verlag, S. 33-72.

Fuchs, Dieter, Jürgen Gerhards and Edeltraud Roller (1993): "Wir und die anderen. Ethnozentrismus in den zwölf Ländern der europäischen Gemeinschaft," in: Kölner Zeitschrift für Soziologie und Sozialpsychologie 45: 238-253.

Fuchs, Dieter, and Hans-Dieter Klingemann (2000): A Comparison of Democratic Communities: American Exceptionalism and European Etatism, Paper presented at the Conference "Re-thinking Democracy in the New Millennium" at the University of Houston, $17^{\text {th }}-20^{\text {th }}$ February 2000.

Fuchs, Dieter, and Edeltraud Roller (1998): "Cultural Conditions of Transition to Liberal Democracies in Central and Eastern Europe," in: Samuel H. Barnes and János Simon (eds.): The Postcommunist Citizen, Budapest: Erasmus Foundation and Hungarian Academy of Sciences, pp. 35-77. 
Fukuyama, Francis (1999): The Great Disruption. Human Nature and the Reconstitution of Social Order, New York: Free Press.

Gerhards, Jürgen (1993): "Westeuropäische Integration und die Schwierigkeiten der Entstehung einer europäischen Öffentlichkeit," in: Zeitschrift für Soziologie 22: 96-110. Grimm, Dieter (1995): „Does Europe Need a Constitution?,“ in: European Law Journal 1: 282-302.

Hansen, Mogens H. (1991): The Athenian Democracy in the Age of Demosthenes. Structure, Principles and Ideology, Oxford: Blackwell.

Huntington, Samuel P. (1996): The Clash of Civilizations and the Remaking of World Order, New York: Simon \& Schuster.

Inglehart, Ronald (1998): Clash of Civilizations of Global Cultural Modernization? Empirical Evidence from 61 Societies, Paper presented at the 1998 meeting of the International Sociological Association, Montreal, August 27-31, 1998.

Kielmansegg, Peter Graf (1996): "Integration und Demokratie,” in: Markus Jachtenfuchs and Beate Kohler-Koch (eds.): Europäische Integration, Opladen: Leske + Budrich, pp. 47-71.

Klingemann, Hans-Dieter (1999): "Mapping Political Support in the 1990s: A Global Analysis," in: Pippa Norris (ed.): Critical Citizens: Global Support for Democratic Government, Oxford/New York: Oxford University Press, pp. 31-56.

Klingemann, Hans-Dieter (2000): "Negative Parteiorientierung und repräsentative Demokratie. Eine vergleichende Analyse," in: Oskar Niedermayer and Bettina Westle (eds.): Demokratie und Partizipation, Festschrift für Max Kaase, Opladen: Westdeutscher Verlag, pp. 281-312.

Klingemann, Hans-Dieter, and Richard I. Hofferbert (2000): “The Capacity of New Party Systems to Channel Discontent," in: Hans-Dieter Klingemann and Friedhelm Neidhardt (eds.): Zur Zukunft der Demokratie, Berlin: edition sigma (forthcoming).

Lepsius, M. Rainer (1999): „Die Europäische Union. Ökonomisch-politische Integration und kulturelle Pluralität,“ in: Reinhold Viehoff and Rien T. Segers (eds.): Kultur, Identität, Europa. Über die Schwierigkeiten und Möglichkeiten einer Konstruktion, Frankfurt a. M.: Suhrkamp, pp. 201-222.

Lipset, Seymour Martin (1959): "Some Social Requisites of Democracy," in: American Political Science Review 53: 69-105.

Lipset, Seymour Martin (1994): “The Social Requisites of Democracy Revisited," in: American Sociological Review 59: 1-22.

Lipset, Seymour Martin (1996): American Exceptionalism. A Double-Edged Sword, New York: W. W. Norton. 
Lipset, Seymour Martin (2000): “Conditions for Democracy," in: Hans-Dieter Klingemann and Friedhelm Neidhardt (eds.): Zur Zukunft der Demokratie, Berlin: edition sigma (forthcoming).

Nozick, Robert (1974): Anarchy, State, and Utopia, New York: Basic Books.

Post, Robert C. (1993): "Between Democracy and Community: The Legal Constitution of Social Form," in: John W. Chapman and Ian Shapiro (eds.): Democratic Community. Nomos No. XXXV, New York: New York University Press, pp. 163-190.

Putnam, Robert D., with Robert Leonardi and Raffaella Y. Nanetti (1993): Making Democracy Work: Civic Traditions in Modern Italy, Princeton, N.J.: Princeton University Press.

Rawls, John (1993): Political Liberalism, New York: Columbia University Press.

Reisinger, William M. (1999): Reassessing Theories of Transition away from Authoritarian Regimes: Regional Patterns among Postcommunist Countries, Paper presented at the 1999 Annual Meeting of the Midwest Political Science Association, April 15-17. 1999, Chicago.

Rohrschneider, Robert (1999): Learning Democracy. Democratic and Economic Values in Unified Germany, Oxford: Oxford University Press.

Roller, Edeltraud (2000): "Ende des sozialstaatlichen Konsenses? Zum Aufbrechen traditioneller und zur Entstehung neuer Konfliktstrukturen in Deutschland,“ in: Oskar Niedermayer and Bettina Westle (eds.), Demokratie und Partizipation, Opladen: Westdeutscher Verlag, pp. 88-114.

Rothstein, Bo (1998): Just Institutions Matter. The Moral and Political Logic of the Universal Welfare State, Cambridge: University Press.

Sartori, Giovanni (1987): The Theory of Democracy Revisited, Chatham, N.J.: Chatham House.

Scharpf, Fritz W. (1999): "Demokratieprobleme in der europäischen Mehrebenenpolitik," in: Wolfgang Merkel and Andreas Busch (eds.): Demokratie in Ost und West. Für Klaus von Beyme, Frankfurt a. M.: Suhrkamp, pp. 672-694. 